\title{
Implementation and assessment of a carbonate system model (Eco3M-CarbOx v1.1) in a highly dynamic Mediterranean coastal site (Bay of Marseille, France)
}

\author{
Katixa Lajaunie-Salla ${ }^{1}$, Frédéric Diaz ${ }^{1}$, Cathy Wimart-Rousseau ${ }^{1}$, Thibaut Wagener $^{1}$, Dominique Lefèvre ${ }^{1}$, \\ Christophe Yohia $^{2}$, Irène Xueref-Remy ${ }^{3}$, Brian Nathan ${ }^{3}$, Alexandre Armengaud ${ }^{4}$, and Christel Pinazo ${ }^{1}$ \\ ${ }^{1}$ Aix Marseille Univ., Université de Toulon, CNRS, IRD, MIO, UM 110, 13288, Marseille, France \\ ${ }^{2}$ Aix Marseille Univ., CNRS, IRD, OSU Institut Pythéas, 13288, Marseille, France \\ ${ }^{3}$ Aix Marseille Univ., Université d'Avignon, CNRS, IRD, IMBE, Marseille, France \\ ${ }^{4}$ AtmoSud: Observatoire de la qualité de l'air en région Sud Provence Alpes Côte d'Azur, \\ le Noilly Paradis, 146 rue Paradis, 13294 Marseille, France
}

Correspondence: Katixa Lajaunie-Salla (katixa.lajaunie@gmail.com) and Fredéric Diaz (frederic.diaz@univ-amu.fr)

Received: 16 February 2020 - Discussion started: 18 May 2020

Revised: 17 November 2020 - Accepted: 26 November 2020 - Published: 19 January 2021

\begin{abstract}
A carbonate chemistry balance module was implemented into a biogeochemical model of the planktonic food web. The model, named Eco3M-CarbOx, includes 22 state variables that are dispatched into 5 compartments: phytoplankton, heterotrophic bacteria, detrital particulate organic matter, labile dissolved organic, and inorganic matter. This model is applied to and evaluated in the Bay of Marseille (BoM, France), which is a coastal zone impacted by the urbanized and industrialized Aix-Marseille Metropolis, and subject to significant increases in anthropogenic emissions of $\mathrm{CO}_{2}$.

The model was evaluated over the year 2017, for which in situ data of the carbonate system are available in the study site. The biogeochemical state variables of the model only change with time, to represent the time evolution of a sea surface water cell in response to the implemented realistic forcing conditions. The model correctly simulates the value ranges and seasonal dynamics of most of the variables of the carbonate system except for the total alkalinity. Several numerical experiments were conducted to test the response of carbonate system to (i) a seawater temperature increase, (ii) wind events, (iii) Rhône River plume intrusions, and (iv) different levels of atmospheric $\mathrm{CO}_{2}$ contents. This set of numerical experiments shows that the Eco3M-CarbOx model provides expected responses in the alteration of the marine carbonate balance regarding each of the considered pertur-
\end{abstract}

bation. When the seawater temperature changes quickly, the behavior of the BoM waters alters within a few days from a source of $\mathrm{CO}_{2}$ to the atmosphere to a sink into the ocean. Moreover, the higher the wind speed is, the higher the airsea $\mathrm{CO}_{2}$ gas exchange fluxes are. The river intrusions with nitrate supplies lead to a decrease in the $p \mathrm{CO}_{2}$ value, favoring the conditions of a sink for atmospheric $\mathrm{CO}_{2}$ into the BoM. A scenario of high atmospheric concentrations of $\mathrm{CO}_{2}$ also favors the conditions of a sink for atmospheric $\mathrm{CO}_{2}$ into the waters of the BoM. Thus the model results suggest that external forcings have an important impact on the carbonate equilibrium in this coastal area.

\section{Introduction}

Current climate change mostly originates from the carbon dioxide $\left(\mathrm{CO}_{2}\right)$ increase in the atmosphere at a high annual rate $(+2.63 \mathrm{ppm}$ from May 2018 to May 2019, https:/www.esrl.noaa.gov/gmd/ccgg/trends/global.html, last access: September 2019). This atmospheric $\mathrm{CO}_{2}$ increase impacts the carbonate chemistry equilibrium of the oceanic water column (Allen et al., 2009; Matthews et al., 2009). Oceans are known to act as a sink for anthropogenic $\mathrm{CO}_{2}$, i.e., $30 \%$ of emissions, which leads to a marine acidification (Gruber et al., 2019; Orr et al., 2005; Le Quéré et al., 2018). 
$\mathrm{CO}_{2}$ is a key molecule in the biogeochemical functioning of the marine ecosystem. Photo-autotrophic organisms, mainly phytoplankton and macro-algae, fix this gas through photosynthesis in the euphotic zone and, in turn, produce organic matter and dissolved oxygen. Heterotrophic organisms, mainly heterotrophic protists and metazoans, consume organic matter and dissolved oxygen by aerobic respiration and, in turn, produce $\mathrm{CO}_{2}$. In the ocean, the main processes regulating $\mathrm{CO}_{2}$ exchanges between the atmosphere and sea are the solubility pump and the biological pump at different timescales. Overall, the thermohaline gradients drive the solubility pump, while the metabolic processes of gross primary production and respiration set the intensity of the biological pump (Raven and Falkowski, 1999).

The coastal zones, despite their small surface area and volume compared to those of the open ocean, have a large influence upon carbon dynamics and represent $14 \%$ to $30 \%$ of the oceanic primary production (Gattuso et al., 1998). At the interface between open ocean and continents, these zones receive large inputs of nutrients and organic matter from rivers, groundwater discharge, and from atmospheric depositions (Cloern et al., 2014; Gattuso et al., 1998). On coasts, shorelines are subject to an increasing density of population and associated urbanization (Small and Nicholls, 2003). This rapid alteration of shorelines all over the world accelerates the emissions of greenhouses gases near the coastal ocean, and it also involves large discharges of material into the seawater by wastewater runoff and/or rivers (Cloern, 2001). These anthropogenic forcings alter the biogeochemical functioning of these zones and could lead to a growing eutrophication (Cloern, 2001). Moreover, these forcings could affect the carbonate chemistry dynamics and amplify or attenuate the acidification in coastal zones. This alteration of the marine environment may provoke further changes in the structure of the plankton community, including, in fine, consequences on the populations with high trophic levels, such as teleosts (Esbaugh et al., 2012). At the global scale, coastal zones are considered to be a significant sink for atmospheric $\mathrm{CO}_{2}$, with an estimated flux converging to $0.2 \mathrm{PgC} \mathrm{yr}^{-1}$ (Roobaert et al., 2019). However, some studies highlight that the status of these areas as a net sink or source still remains uncertain due to the complexity of the interactions between biological and physical processes, and also due to the lack of in situ measurements (Borges and Abril, 2011; Chen et al., 2013; Chen and Borges, 2009). Moreover, the capacity for coastal zones to absorb atmospheric $\mathrm{CO}_{2}$ resulting from the increasing human pressure also remains poorly known. There are few works which highlight, under future atmospheric $\mathrm{CO}_{2}$ levels, whether coastal zones will become a net sink or a reduced source of $\mathrm{CO}_{2}$ (Andersson and Mackenzie, 2012; Cai, 2011).

The current increase in the atmospheric $\mathrm{CO}_{2}$ partial pressure $\left(p \mathrm{CO}_{2}\right)$ is slowly shifting the marine carbonate chemistry equilibrium towards increases in the seawater $p \mathrm{CO}_{2}$ and bicarbonate ions $\left(\mathrm{HCO}_{3}^{-}\right)$and decreases in $\mathrm{pH}$ and carbon- ate ions $\left(\mathrm{CO}_{3}^{2-}\right)$ (Hoegh-Guldberg et al., 2018). These trends were already described in several coastal and open-ocean locations worldwide (Cai et al., 2011). In a coastal northwestern Mediterranean site, a 10-year time series of in situ measurements highlights a trend of $\mathrm{pH}$ decrease and $p \mathrm{CO}_{2}$ increase (Kapsenberg et al., 2017). Low pH values can inhibit the ability of many marine organisms to form the calcium carbonate $\left(\mathrm{CaCO}_{3}\right)$ used in the making of skeletons and shells (Gattuso et al., 2015). In an extreme case, this shift may promote dissolution of $\mathrm{CaCO}_{3}$ because the water will become under-saturated with respect to $\mathrm{CaCO}_{3}$ minerals (Doney et al., 2009).

The present study is dedicated to the implementation of a carbonate system module into a preexisting biogeochemical model of the planktonic food web. This new model, named Eco3M-CarbOx (v1.1), is then evaluated in a highly dynamic coastal site, i.e., the Bay of Marseille (BoM) in the northwestern Mediterranean Sea. This evaluation is performed on the seasonal dynamics of biogeochemical and carbonate modeled variables against that of the corresponding in situ data available over the year 2017. This study is extended by a fine analysis of the variability of the marine carbonate system (stocks, fluxes) in relation to physical (e.g., wind events, river intrusions, temperature increases, changes in the atmospheric $p \mathrm{CO}_{2}$ levels) and biogeochemical processes (gross primary production (GPP) and respiration, $R$ ) in the study site. The BoM is suitable for this kind of study because this coastal area is subject to high emissions of atmospheric $\mathrm{CO}_{2}$ from the nearby urban area, and it also receives effluents from the Aix-Marseille metropolis. In addition, strong wind events (the mistral) regularly occur, which could lead to (i) strong latent heat losses at the surface (Herrmann et al., 2011) and upwelling along the coast with a common consequence of a cooling effect and (ii) Rhône River plume intrusion under specific wind conditions (Fraysse et al., 2013, 2014). In this regional context, many anthropogenic forcings can interact with the dynamics of the carbonate systems. Natural determinants of the composition of the marine planktonic community can also play a crucial role in these dynamics.

\section{Materials and methods}

\subsection{Numerical model description}

The Eco3M-CarbOx biogeochemical model was developed to represent the dynamics of the seawater carbonate system and plankton food web in the BoM. The model was implemented using the Eco3M (Ecological Mechanistic and Modular Modelling) platform (Baklouti et al., 2006). The model structure used is based on an existing model of the plankton ecosystem (Fraysse et al., 2013), including a description of carbon $(\mathrm{C})$, nitrogen $(\mathrm{N})$, and phosphorus $(\mathrm{P})$ marine biogeochemical cycles. The Eco3M-CarbOx model includes 22 prognostic state variables that are split into several 


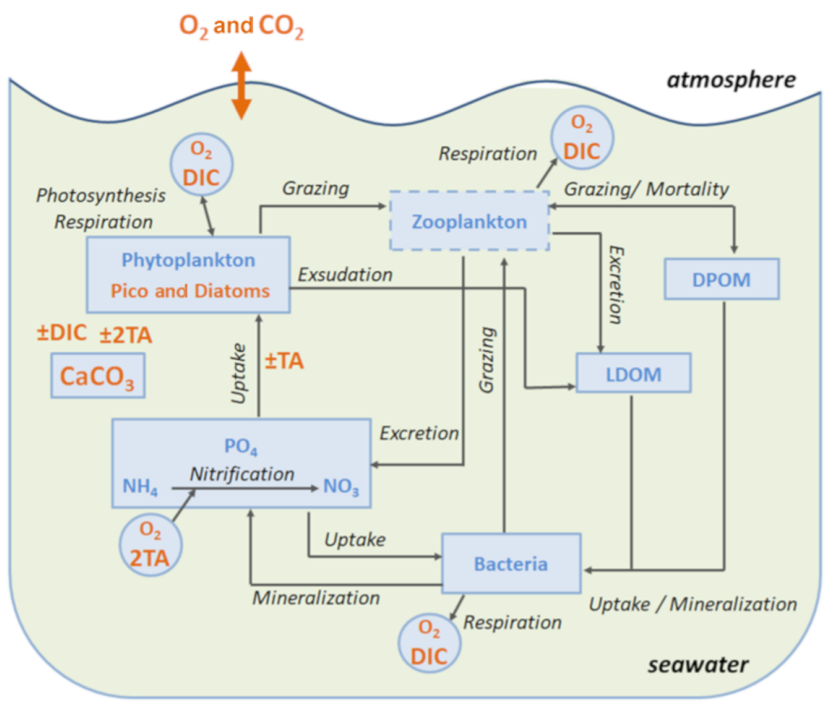

Figure 1. Schematic diagram of the biogeochemical model Eco3MCarbOx. Explicit state variables of the model are indicated in continuous-line box or circles except the implicit variable for zooplankton (dotted line box). State variables written in orange are added variables compared to the preexisting biogeochemical model of Fraysse et al. (2013). Arrows represent processes between two state variables. TA: total alkalinity; DIC: dissolved inorganic carbon; $\mathrm{CO}_{2}$ : dissolved carbon dioxide; $\mathrm{O}_{2}$ : dissolved oxygen; $\mathrm{CaCO}_{3}$ : calcium carbonate.

compartments: phytoplankton, heterotrophic bacteria, detrital particulate organic matter, labile dissolved organic matter, nutrients (ammonia, nitrate, and phosphate), dissolved oxygen, and carbonate system variables (Fig. 1). In this study, the state variables of the Eco3M-CarbOx model only change over time (i.e., usually termed "model $0 \mathrm{D}$ "); they are representative of the time evolution of a sea surface water cell, but this biogeochemical model is not coupled with a hydrodynamic model.

The model presented in this study includes a set of new developments and improvements in the realism of the plankton web structure and process formulations compared to the model of Fraysse et al. (2013). In order to improve the representation of chlorophyll concentration in the Bay of Marseille the phytoplankton is divided into two groups: one with some ecological and physiological traits of the Synechococcus cyanobacteria, which is one of the major constitutive members of pico-autotrophs in the Mediterranean Sea (Mella-Flores et al., 2011), and another with traits of large diatoms, which are generally observed during spring blooms at mid-latitudes (Margalef, 1978). For both of the phytoplankton, there is a diagnostic chlorophyll $a$ variable related to the phytoplankton $\mathrm{C}$ biomass, the phytoplankton N-to-C ratio, and the limiting internal ratio $f_{Q}^{N}$ (Faure et al., 2010; Smith and Tett, 2000; Table B2, Appendix B). The functional response of primary production was modified using another formulation of the temperature limitation function which takes into account the optimal temperature of growth for each phytoplankton group. The exudation of phytoplankton was modified taking into account the intracellular phytoplankton ratio. For the uptake of matter by bacteria and the remineralization processes the dependence on the intracellular bacteria ratio was modified. A temperature dependence of all biogeochemical processes was added to take into account the effects of rapid and strong variations of seawater temperature on plankton during episodes of upwelling, for instance, that are usually observed in the BoM. Also certain parameters in some formulations were modified owing to the alterations of some formulations (Table B4, Appendix B).

Additionally, a carbonate system module was developed and three state variables were added: dissolved inorganic carbon (DIC), total alkalinity (TA) and the calcium carbonate $\left(\mathrm{CaCO}_{3}\right)$ implicitly representing calcifying organisms. The knowledge of DIC and TA allows the calculation of the $p \mathrm{CO}_{2}$ and $\mathrm{pH}$ (total $\mathrm{pH}$ scale) diagnostic variables, necessary for resolving all the equations of the carbonate system. These equations use apparent equilibrium constants, which depend on temperature, pressure, and salinity (Dickson, 1990a, b; Dickson and Riley, 1979; Lueker et al., 2000; Millero, 1995; Morris and Riley, 1966; Mucci, 1983; Riley, 1965; Riley and Tongudai, 1967; Uppström, 1974; Weiss, 1974). The details of the resolution of carbonate system module are given in Appendix A. For this module three processes were also added: the precipitation and dissolution of calcium carbonate and the gas exchange of $p \mathrm{CO}_{2}$ with the atmosphere. Based on the review of Middelburg (2019), it is considered that (i) TA decreases by 2 moles for each mole of $\mathrm{CaCO}_{3}$ precipitated, by 1 mole for each mole of ammonium nitrified, by 1 mole for each mole of ammonium assimilated by phytoplankton, and TA increases by 2 moles for each mole of $\mathrm{CaCO}_{3}$ dissolved, and by 1 mole for each mole of organic matter mineralized by bacteria in ammonium (Table B2, Appendix B); (ii) DIC is consumed during the photosynthesis and calcification processes and is produced by respiration (of phytoplankton, zooplankton, and bacteria) and the $\mathrm{CaCO}_{3}$ dissolution processes. Moreover, the dynamics of DIC are altered by the $\mathrm{CO}_{2}$ exchanges with the atmosphere (Table B2, Appendix B). The air-sea $\mathrm{CO}_{2}$ fluxes are calculated from the $p \mathrm{CO}_{2}$ gradient across the air-sea interface and the gas transfer velocity (Table B3, Appendix B) estimated from the wind speed and using the parametrization of Wanninkhof (1992).

In the Eco3M-CarbOx model, zooplankton is considered as an implicit variable. However, a closure term based on the assumption that all of the matter grazed by the zooplankton and higher trophic levels return as either organic or inorganic matter by excretion, egestion, and mortality processes is taken into account (Fraysse et al., 2013). The model considers a "non-Redfieldian" stoichiometry for phytoplankton and bacteria. All the biogeochemical model formulations, equations, and associated parameter values are detailed in Appendix B. 


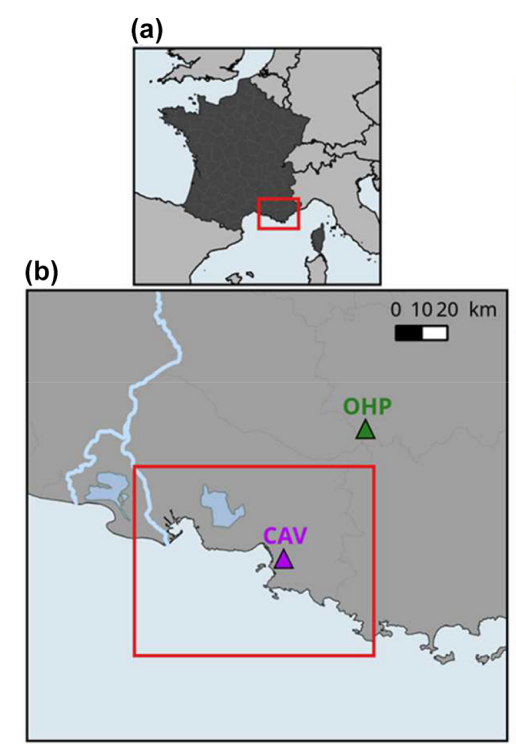

(c)

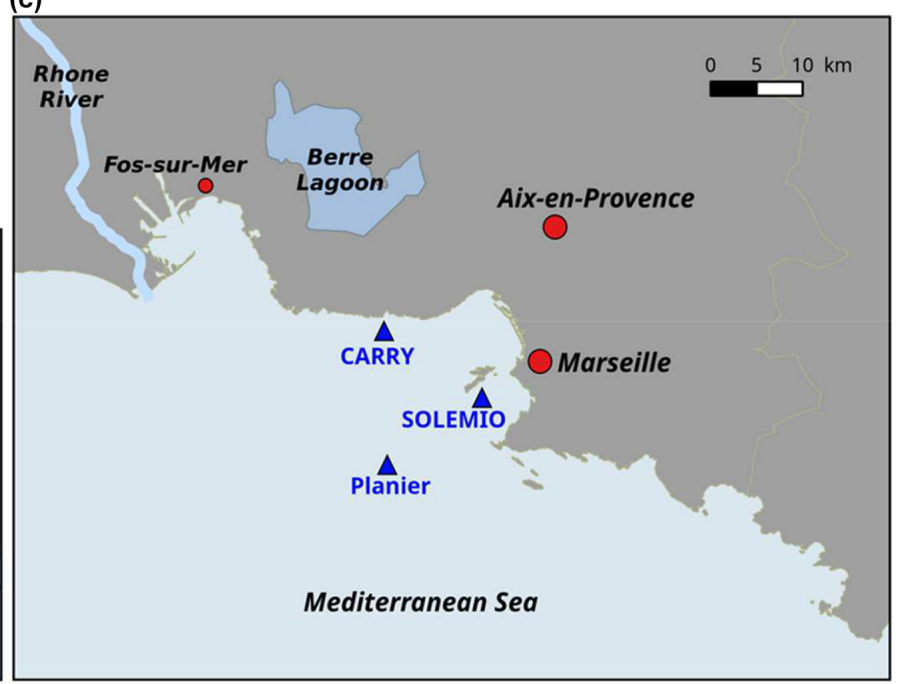

Figure 2. Map of study area: the Region Sud (a), Aix-Marseille Metropolis (area in the red rectangle) (b), the Bay of Marseille (c). $\mathrm{CAV}=$ Cinq Avenues Station (urban site); OHP: Observatoire de Haute Provence station (non-urban site); Carry, Solemio, Planier: marine study sites in the Bay of Marseille.

\subsection{Study area}

The BoM is located in the eastern part of the Gulf of Lion, in the northwestern Mediterranean Sea (Fig. 2). The city of Marseille, located on the coast of the BoM, is the second largest city of France, with a population of ca. 1 million. The Rhône River, which flows into the Gulf of Lion, is the greatest source of freshwater and nutrients for the Mediterranean Sea, with a river mean flow of $1800 \mathrm{~m}^{3} \mathrm{~s}^{-1}$ (Pont et al., 2002). Several studies highlight the eastward intrusion events from the Rhône River plume in the BoM under east and southeasterly wind conditions, which favor biological productivity (Fraysse et al., 2014; Gatti et al., 2006; Para et al., 2010). The biogeochemistry of the BoM is complex and highly driven by hydrodynamics. For example, northnorthwesterly winds induce upwelling events which bring cold and nutrient-rich waters upward (Fraysse et al., 2013). Moreover, the oligotrophic Northern Current occasionally intrudes into the BoM (Petrenko, 2003; Ross et al., 2016).

Despite the presence of several marine protected areas around the BoM (the Regional Park of Camargue, the Marine protected area Côte Bleue, and the National Park of Calanques), it is strongly impacted by diverse anthropogenic forcing, because industrialized and urbanized areas are located all along the coast. From the land, the BoM receives nutrients and organic matter from the urban area of the Aix-Marseille metropolis (Millet et al., 2018), the industrialized area of Fos-sur-Mer (one of the biggest oil-based industry areas in Europe), and the Berre Lagoon, which is eutrophized (Gouze et al., 2008; Fig. 2c). From the atmosphere, the BoM is subject to fine-particle deposition and greenhouse gas emissions (including $\mathrm{CO}_{2}$ ) from the nearby urban area, and it also receives effluents from the Aix-Marseille metropolis.

\subsection{Dataset}

The modeled variables of the carbonate system (DIC, TA, $\mathrm{pH}$, and $p \mathrm{CO}_{2}$ ) and chlorophyll $a$ are hereafter compared to observations collected at the SOLEMIO station (Figs. 2c and 3), which is a component of the French national monitoring network (Service d'Observation en Milieu Littoral SOMLIT, http://somlit.epoc.u-bordeaux1.fr/fr/, last access: January 2020). Major biogeochemical parameters have been recorded since 1994. Carbonate chemistry variables $(\mathrm{pH}$, $p \mathrm{CO}_{2}$, DIC, and TA), sampled every 2 weeks, have been available since 2016 .

\subsection{Design of numerical experiments}

In the present work, the Eco3M-CarbOx model was run for the whole year of 2017. This year was chosen because in situ data of carbonate systems (DIC, TA, $\mathrm{pH}$, and $p \mathrm{CO}_{2}$ ) are available for the whole year at the SOLEMIO station (Fig. 2c). The biogeochemical variables were initialized using in situ data from winter conditions (Table B1, Appendix B). The model was forced by time series of sea surface temperature and salinity, wind (at $10 \mathrm{~m}$ ), light, and atmospheric $\mathrm{CO}_{2}$ concentrations. The sea temperature time series is from in situ hourly data recorded at the Planier station (Fig. 2c). For salinity, hourly in situ data from the SOLEMIO station and from the CARRY buoy were used (Fig. 2c). Wind and light hourly time series were extracted from the WRF meteorological model at the SOLEMIO sta- 
Table 1. Forcing of the different scenarios $(S)$ simulated with the model. See Sect. 2.4 for details of the scenarios.

\begin{tabular}{lllll}
\hline & Temperature & Wind & River input & Atmospheric $\mathrm{CO}_{2}$ \\
\hline$S 0-$ Reference & In situ data of 2017 & WRF model 2017 & No & CAV station 2017 \\
$S 1-T$ increases & In situ data of $2017+1.5^{\circ} \mathrm{C}$ & WRF model 2017 & No & CAV station 2017 \\
$S 2-$ Wind constant & In situ data of 2017 & $7 \mathrm{~m} \mathrm{~s}^{-1}$ & No & CAV station 2017 \\
$S 3-$ Wind events & In situ data of 2017 & $3 \mathrm{~d}$ at $20 \mathrm{~m} \mathrm{~s}^{-1}$ & No & CAV station 2017 \\
$S 4-\mathrm{NO}_{3}$ & In situ data of 2017 & WRF model 2017 & Yes, $\mathrm{NO}_{3}$ & CAV station 2017 \\
$S 5-$ Non-urban & In situ data of 2017 & WRF model 2017 & No & OHP station 2017 \\
\hline
\end{tabular}

tion (Yohia, 2017). Finally, we used hourly atmospheric $\mathrm{CO}_{2}$ values from in situ measurements recorded at the Cinq Avenues station (CAV station; Fig. 2b) by the AtmoSud Regional Atmospheric Survey Network, France (https://www. atmosud.org, last access: August 2019). This simulation is the reference simulation (noted $S 0$ ). As highlighted previously, Rhône River plume intrusions (due to wind-specific conditions) have an impact on the dynamics of primary production (Fraysse et al., 2014; Ross et al., 2016) and then on the seawater carbonate system. Moreover, the seawater temperature and atmospheric $\mathrm{CO}_{2}$ variations control the seawater $\mathrm{CO}_{2}$ dynamics via the solubility equilibrium and gas exchange with the atmosphere (Middelburg, 2019). In order to quantify the impact of different forcing, several simulations (hereafter noted $S$ ), which are summarized in Table 1, were conducted:

- Impact of seawater temperature increase, $S 1$. The forcing time series of in situ temperatures was shifted by $+1.5^{\circ} \mathrm{C}$ (Cocco et al., 2013).

- Impact of wind events. A first simulation $S 2$ was run with a constant wind intensity of $7 \mathrm{~m} \mathrm{~s}^{-1}$ (2017 annual average wind speed) throughout the year and a second one (S3) with two three-day periods of strong wind speed $\left(20 \mathrm{~m} \mathrm{~s}^{-1}\right)$ representative of short bursts of the mistral (data not shown) starting on 15 May and $15 \mathrm{Au}-$ gust, and a constant value of $7 \mathrm{~m} \mathrm{~s}^{-1}$ the rest of the year.

- Impact of nutrient supply (nitrate) during a Rhône River plume intrusion (S4). A threshold of 37 has been chosen to identify the presence of low-salinity waters from the Rhône River plume in the forcing file of salinity. Here, concentrations in nitrate supplied by the river depend on the salinity. A relationship between these two variables was then established for the SOLEMIO point from the MARS3D-RHOMA coupled physical and biogeochemical model (Fraysse et al., 2013; Pairaud et al., 2011). This relationship has already been used successfully to reproduce realistic observed conditions in the studies of Fraysse et al. (2014) and Ross et al. (2016): $\mathrm{NO}_{3 \text { intrusion }}$ $\left(\mathrm{mmolm} \mathrm{m}^{-3}\right)=-1.70 \times S+65$.

- Non-urban atmospheric $\mathrm{CO}_{2}$ concentrations (S5). This simulation takes into account the forcing of atmo- spheric $\mathrm{CO}_{2}$ values measured at the Observatoire de Haute Provence station (OHP; Fig. 2b), located outside of the Aix-Marseille metropolis, by the ICOS National Network, France (http://www.obs-hp.fr/ICOS/ Plaquette-ICOS-201407_lite.pdf, last access: August 2019).

In this work, we calculated the daily mean values of state variables, statistical parameters, and mean fluxes of modeled processes throughout the year and over two main hydrological periods: the stratified and mixed water column periods. The stratified water column (SWC) is defined with a temperature difference between the surface and bottom of more than $0.5^{\circ} \mathrm{C}$ (Monterey and Levitus, 1997). For the simulated year (2017), the SWC period lasts from 10 May to 20 October. The mixed water column (MWC) period corresponds to the rest of the year.

\section{Results}

\subsection{Model skills}

Following the recommendations of Rykiel (1996), three criteria were considered to evaluate the performance of our model:

- Does the model reproduce the timing of the observed variations of carbonate system at the seasonal timescale?

- Does the model reproduce the observed $p \mathrm{CO}_{2}$ and $\mathrm{pH}$ ranges at the seasonal timescale?

- Are the observations correctly represented according to the Willmott skill score (WSS)? This index is an objective measurement of the degree of agreement between the modeled results and the observed data. A correct representation of observations by the model is achieved when this index is higher than 0.70 (Willmott, 1982).

Over most of the studied period, the model simulates lower chlorophyll $a$ concentrations than the in situ observations, especially during the MWC period (Fig. 3a). Two maxima of chlorophyll $a$ concentrations are observed in situ: the first one at ca. $1.71 \mathrm{mg} \mathrm{m}^{-3}$ in March and the second one at ca. 

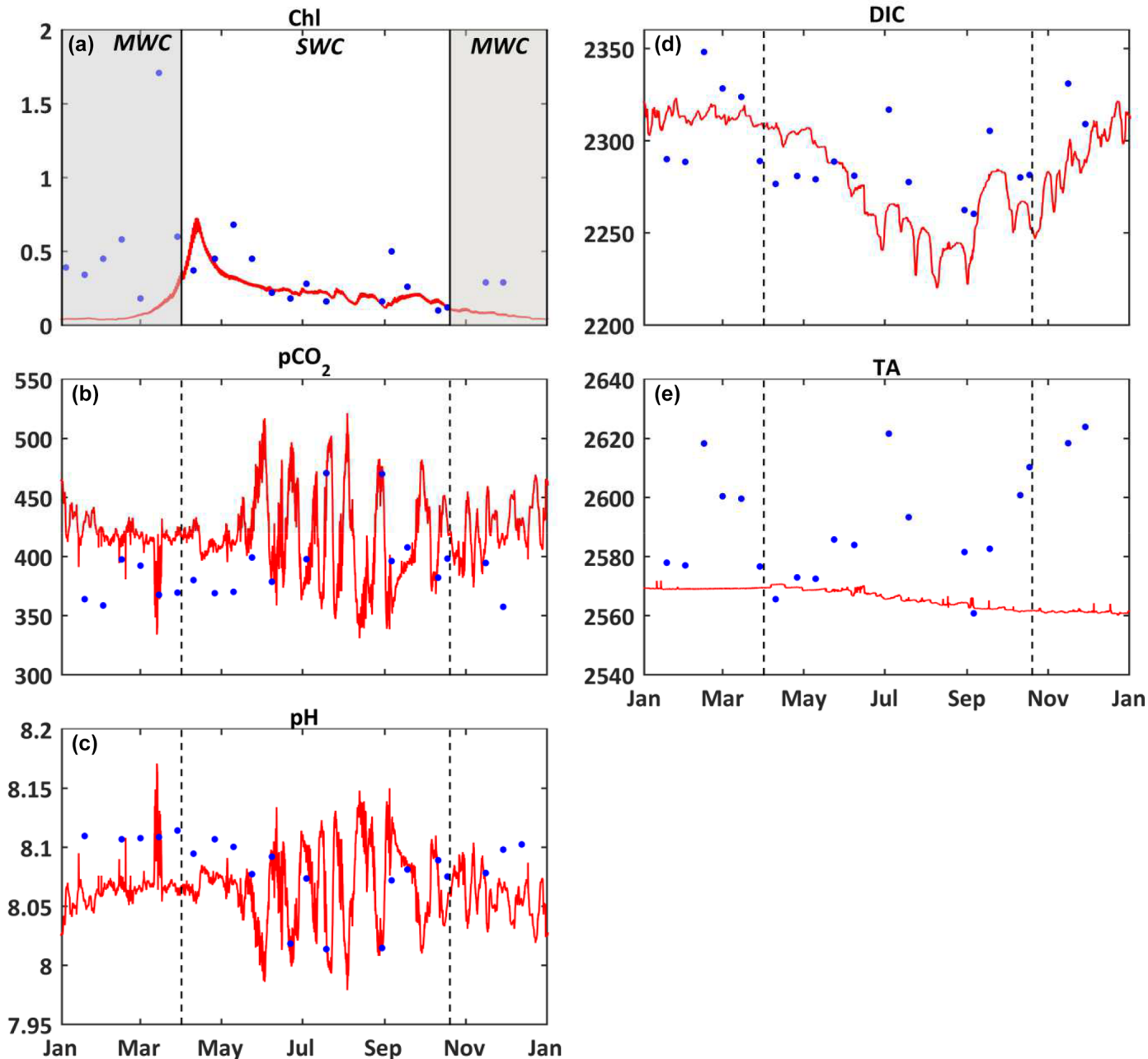

Figure 3. Comparison of model results (red) and in situ data (blue) at the surface of the SOLEMIO station. (a) Chlorophyll $a$ concentrations $\left(\mathrm{mg} \mathrm{m}^{-3}\right)$, (b) $p \mathrm{CO}_{2}(\mu \mathrm{atm}),(\mathbf{c}) \mathrm{pH},(\mathbf{d}) \mathrm{DIC}\left(\mu \mathrm{mol} \mathrm{kg}{ }^{-1}\right),(\mathbf{e}) \mathrm{TA}\left(\mu \mathrm{mol} \mathrm{kg}{ }^{-1}\right)$. The value of each state variable represents the mean around $\pm 5 \mathrm{~d}$ of the seawater sampling date. The shaded area and dotted black line delimit the SWC and MWC periods.

Table 2. Statistical evaluation of observations vs. model for 2017: observed and simulated minimum and maximum values. WSS $=$ Willmott skill score; $N=$ number of measurements. Units of bias are those of modeled variables: chlorophyll $a\left(\mathrm{Chl}_{a}, \mathrm{mg} \mathrm{m}^{-3}\right)$, seawater partial pressure of $\mathrm{CO}_{2}$ (seawater $\left.p \mathrm{CO}_{2}, \mu \mathrm{tm}\right), \mathrm{pH}$, dissolved inorganic carbon (DIC, $\mu \mathrm{mol} \mathrm{kg}{ }^{-1}$ ), and total alkalinity $\left(\mathrm{TA}, \mu \mathrm{mol} \mathrm{kg}{ }^{-1}\right.$ ).

\begin{tabular}{lrrrrr}
\hline & $\mathrm{Chl} a$ & Seawater $\mathrm{pCO}_{2}$ & $\mathrm{pH}$ & $\mathrm{DIC}$ & $\mathrm{TA}$ \\
\hline Obs. min-max & {$[0.10-1.71]$} & {$[358-471]$} & {$[8.014-8.114]$} & {$[2260-2348]$} & {$[2561-2624]$} \\
Mod. min-max & {$[0.03-0.73]$} & {$[331-522]$} & {$[7.979-8.171]$} & {$[2220-2323]$} & {$[2560-2572]$} \\
Bias & -0.22 & 22.47 & -0.016 & -8.48 & -24.91 \\
WSS & 0.36 & $0.69^{*}$ & $0.75^{*}$ & $0.71^{*}$ & 0.43 \\
$N$ & 22 & 20 & 21 & 20 & 20 \\
\hline
\end{tabular}

* Significant value of WSS $(>0.70)$.

$0.68 \mathrm{mg} \mathrm{m}^{-3}$ in May. They are both linked to Rhône River plume intrusions. Several in situ maxima between 0.50 and $0.70 \mathrm{mg} \mathrm{m}^{-3}$ are observed between March and April (at the end of the MWC period), and they signaled the spring bloom event (Table 2 and Fig. 3a). The biogeochemical model quan- titatively reproduces the spring bloom observed at the end of the MWC period (Fig. 3a) with a maximum value of ca. $0.69 \mathrm{mg} \mathrm{m}^{-3}$. The model does not catch the two aforementioned maxima of chlorophyll, and it contains a low WSS 
and a strong bias $\left(0.37\right.$ and $+0.22 \mathrm{mg} \mathrm{m}^{-3}$, respectively $-\mathrm{Ta}-$ ble 2).

On the whole, the seasonal variations of the seawater $p \mathrm{CO}_{2}$ are correctly simulated by the biogeochemical model (Fig. 3b), even if the values are rather overestimated during the MWC period. From January to February, the model reproduces the slight decrease in the observed $p \mathrm{CO}_{2}$, and from February to March it reproduces the increase in $p \mathrm{CO}_{2}$ even if the amplitude of this increase remains smaller. In mid-April, during the simulated spring bloom period, the observed drop in $p \mathrm{CO}_{2}$ and increase in $\mathrm{pH}$ are also spotted in the model (Fig. $3 \mathrm{~b}$ and c). The model especially succeeds in reproducing the observed increase in relation to high temperatures during the $\mathrm{SWC}$ period. The reduction of the $\mathrm{CO}_{2}$ solubility due to thermal effects mostly explains the increase in $p \mathrm{CO}_{2}$ during the SWC period. The strong SD of modeled values during the SWC period can be explained by the rapid changes in temperature, probably due to upwelling usually occurring at this time of the year (Millot, 1990). The range of modeled $p \mathrm{CO}_{2}$ values (345-503 $\left.\mu \mathrm{atm}\right)$ encompasses the range of observed values (358-471 $\mu \mathrm{atm}$; Table 2). The statistical analysis provides a mean bias of $+23 \mu \mathrm{atm}$, and a WSS of 0.69 (Table 2).

The seasonal dynamic of $\mathrm{pH}$ is mostly reproduced by the model, and in particular, the decrease during the SWC period (Fig. 3c). However, the modeled $\mathrm{pH}$ is generally underestimated throughout the year, except during the SWC period, with a mean bias of -0.015 (Table 2). The seasonal range is captured by the model with a minimum value during the SWC period (7.994 vs. 8.014 for observations; Table 2) and a maximum one during the MWC period (8.137 vs. 8.114 for observations; Table 2). The statistical analysis highlights an index of agreement between the in situ data and the model outputs higher than 0.70 (Table 2).

The seasonal variations of DIC show the highest values during the MWC period and a decrease (increase) during the beginning (the end) of the SWC period (Fig. 3d). The lowest values are observed during September. The Eco3M-CarbOx model closely matches the seasonal dynamic by reproducing the range of extreme observed values (Table 2). The mean bias is also small $\left(-8.48 \mu \mathrm{mol} \mathrm{kg}{ }^{-1}\right.$; Table 2). More than $70 \%$ (0.73; Table 2) of modeled DIC concentrations are in statistical agreement with the corresponding observations.

The seasonal cycle of measured TA does not show a clear pattern (Fig. 3e). Large variations of values ranging between 2561 and $2624 \mu \mathrm{mol} \mathrm{kg}^{-1}$ (Table 2) are observed, whatever the hydrological season being considered. The biogeochemical model provides almost constant values of around $2570 \mu \mathrm{mol} \mathrm{kg}{ }^{-1}$ all throughout the year, which is lower than in situ data. With a low WSS index of agreement and a large mean bias (Table 2), the model is not able to confidently reproduce the observed variations of TA (Fig. 3e and Table 2).

\subsection{Carbon fluxes and budgets}

For the year 2017, the values of temperature vary between 13.3 and $25.9^{\circ} \mathrm{C}$ (Fig. 4a). The DIC variations closely match those of temperature (correlation coefficient -0.75 ). For example, the spring increase in temperature leads to a decrease in DIC concentrations (Fig. 4a and c), and the minimum values are reached at the end of SWC period. Over the simulated period, the air-sea $\mathrm{CO}_{2}$ fluxes $\left(F_{\text {aera }}\right)$ vary between -14 and $17 \mathrm{mmol} \mathrm{m}^{-3} \mathrm{~d}^{-1}$, with a weakly positive annual budget of $+6 \mathrm{mmol} \mathrm{m}^{-3} \mathrm{yr}^{-1}$ (or $+0.017 \mathrm{mmol} \mathrm{m}^{-3} \mathrm{~d}^{-1}$, Table 3). Then, the BoM waters would act as a net source of $\mathrm{CO}_{2}$ to the atmosphere on an annual basis. However, on a seasonal basis, the BoM waters would change from a net sink during the MWC period $\left(F_{\text {aera }}<0\right.$; Table 3$)$ to a net source during the SWC one ( $F_{\text {aera }}>0$; Table 3$)$.

On an annual basis, the gross primary production (GPP) and total respiration $(R)$ are balanced, leading to a null average net ecosystem production (NEP; NEP $=\mathrm{GPP}-R$ ) (Fig. $4 \mathrm{f}$ and Table 3 ). The intensity of autotrophic respiration $\left(R_{\mathrm{a}}\right)$ is lower than that of primary production (annual mean of 0.065 vs. $-0.413 \mathrm{mmol} \mathrm{m}^{-3} \mathrm{~d}^{-1}$, respectively - Table 3 ), while the zooplankton and bacterial respiration account for an average of $0.348 \mathrm{mmol} \mathrm{m}^{-3} \mathrm{~d}^{-1}$ (Table 3). On a seasonal basis, the model highlights an ecosystem dominated by autotrophy during the MWC period (NEP $>0$; Table 3) and heterotrophy during the SWC period with higher flux values $(\mathrm{NEP}<0$; Table 3$)$. The biogeochemical fluxes show the strongest variations along the SWC period, following those of temperature (Fig. 4f). The maximum GPP occurs in April and is correlated with the maximum chlorophyll concentration. At this time, the ecosystem is autotrophic (NEP $>0$; Fig. 4b and f) and is a net sink for atmospheric $\mathrm{CO}_{2}$, which explains the DIC and seawater $p \mathrm{CO}_{2}$ decreases during the bloom period (Fig. 4c-e)

When looking in detail at the 2017 temperature and salinity time series (Fig. 4a), several crucial events can be seen occurring, including freshwater intrusions (e.g., 15 March and 6 May) into the BoM and large variations of temperature in relation to upwelling events or latent heat losses due to wind bursts. The largest freshwater intrusion from the Rhône River plume occurs in mid-March, with a minimum observed salinity of ca. 32.5 at the SOLEMIO station (Fig. 4a). During this event, the seawater $p \mathrm{CO}_{2}$ decreases and $\mathrm{pH}$ increases concomitantly (Fig. 4c and d). Then, seawater appears to be temporarily under-saturated in $\mathrm{CO}_{2}$, and the $\mathrm{BoM}$ waters thus act as a sink for atmospheric $\mathrm{CO}_{2}$ at the time of intrusion (Fig. 4e).

During the SWC period, upwelling events quickly cool the surface seawater. In two days, from 25 to $27 \mathrm{July}$, the water temperature drops from 24.7 to $16.9^{\circ} \mathrm{C}$ (Fig. $4 \mathrm{~g}$ ). The decrease in temperature corresponds to the increase in DIC concentrations (Fig. 4i). Concomitantly, the value of seawater $p \mathrm{CO}_{2}$ decreases from 497 to $352 \mu \mathrm{atm}$, and $\mathrm{pH}$ increases from 7.99 to 8.12 (Fig. $4 \mathrm{i}$ and j). This event quickly changes 

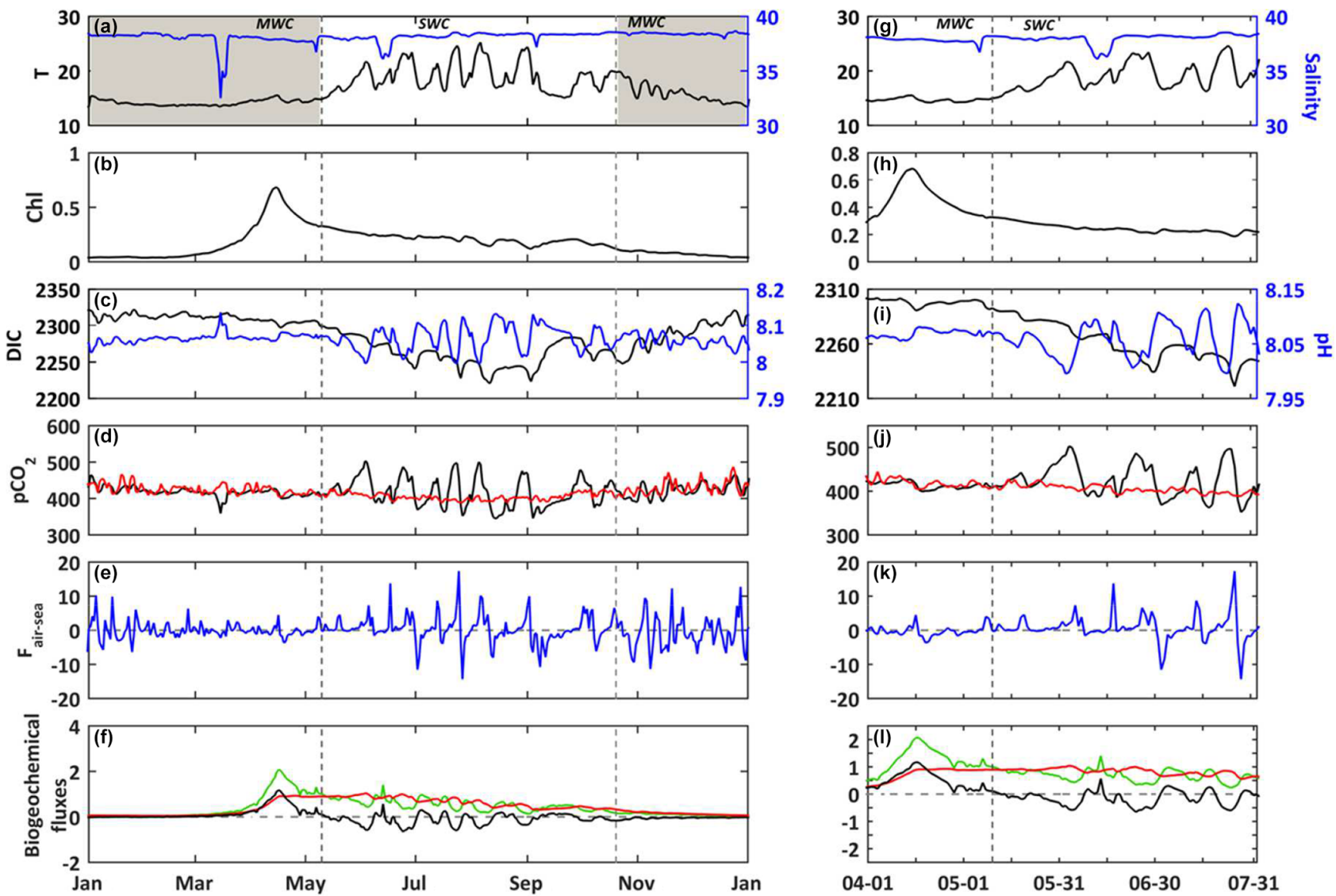

Figure 4. (a-f) 2017. (g-l) Temporal focus between 1 April and 31 July 2017. In situ daily average of (a, g) temperature $\left({ }^{\circ} \mathrm{C}\right.$, black line)

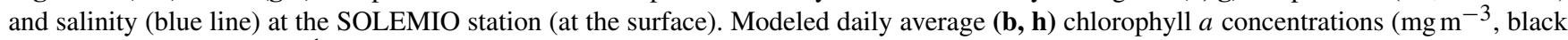
line) (c, i) DIC ( $\mu$ mol kg-1, black line) and $\mathrm{pH}$ (blue line), (d, j) seawater $p \mathrm{CO}_{2}$ ( $\mu$ atm, black line) and atmosphere $p \mathrm{CO}_{2}$ from $\mathrm{OHP}$ ( $\mu$ atm, red line), $(\mathbf{e}, \mathbf{k})$ air-sea $\mathrm{CO}_{2}$ fluxes $\left(\mathrm{mmol} \mathrm{m}^{-3} \mathrm{~d}^{-1}\right)$, (f, l) gross primary production $\left(\mathrm{mmol} \mathrm{m}^{-3} \mathrm{~d}^{-1}\right.$, green line), total respiration $\left(\mathrm{mmol} \mathrm{m} \mathrm{m}^{-3} \mathrm{~d}^{-1}\right.$, red line) and net ecosystem production $\left(\mathrm{mmol} \mathrm{m}^{-3} \mathrm{~d}^{-1}\right.$, black line). The shaded areas and dotted black lines delimit the SWC and MWC periods.

Table 3. Mean flux values ( $m m o l m^{-3} \mathrm{~d}^{-1}$ ) and the contribution of each process to the DIC variations for the reference simulation over the year and SWC/MWC periods.

\begin{tabular}{llrrrrrr}
\hline & & Aeration & GPP & $R_{A}$ & $R_{H}$ & $R$ & NEP \\
\hline \multirow{2}{*}{ Mean flux } & Year & 0.017 & -0.413 & 0.065 & 0.348 & 0.413 & 0 \\
& MWC & -0.245 & -0.314 & 0.052 & 0.176 & 0.228 & 0.086 \\
& SWC & 0.405 & -0.521 & 0.079 & 0.555 & 0.634 & -0.113 \\
\hline \multirow{2}{*}{ Contribution } & Year & $78 \%$ & $11 \%$ & $2 \%$ & $9 \%$ & $11 \%$ & - \\
\hline
\end{tabular}

GPP: gross primary production, $R_{\mathrm{A}}$ : autotrophic respiration, $R_{\mathrm{H}}$ : heterotrophic respiration, NEP: net ecosystem production. 
the BoM waters from a source to a sink for atmospheric $\mathrm{CO}_{2}$ (from +17 to $-14 \mathrm{mmolm}^{-3} \mathrm{~d}^{-1}$; Fig. $4 \mathrm{k}$ ), and also from a net heterotrophic to a net autotrophic ecosystem (Fig. 41).

\subsection{Impact of external forcing on the dynamics of carbonate system}

\subsubsection{Temperature increase}

Here we compare the reference simulation $S 0$ with the $S 1$ simulation (seawater temperature elevation of $1.5^{\circ} \mathrm{C}-$ Fig. 5). During the year, there are few changes on the carbonate system variables such as the $p \mathrm{CO}_{2}$ and $\mathrm{pH}$ (data not shown). The main alterations occur during the blooms of phytoplankton. The simulated bloom of phytoplankton occurs later, at beginning of May, for both diatoms and picophytoplankton, with maximum values of chlorophyll at 1.4 and $0.4 \mathrm{mg} \mathrm{m}^{-3}$, respectively (Fig. 5a and f).

As both the limitations due to light and nutrients remain about the same during the simulations $S 0$ and $S 1$, this counterintuitive occurrence of a bloom relative to changes in temperature is mainly explained by the temperature limiting function, which depends on the optimal temperature of growth $\left(T_{\mathrm{opt}}\right)$. For the picophytoplankton, from January to April, the increase of $1.5^{\circ} \mathrm{C}$ drastically reduces the limitation by temperature (Fig. $5 \mathrm{c}$ ), because the temperature is closer to the optimal temperature $\left(T_{\mathrm{opt}}=16^{\circ} \mathrm{C}\right.$, Table A4) during $S 1$ than $S 0$. In the $S 0$ simulation, the temperature reaches $T_{\mathrm{opt}}$ ca. 15 April and it induces the bloom, while at the same time in $S 1$ the temperature moves slightly away from $T_{\text {opt }}$ and it does not enable the triggering of a bloom. At the time of the bloom in $S 1$, the opposite configuration occurs. In $S 0$, the ambient temperature is again far from $T_{\mathrm{opt}}$, explaining the absence of a bloom, while in the $S 1$ the ambient temperature is closer to $T_{\mathrm{opt}}$, enabling the occurrence of a bloom. The picophytoplankton bloom then occurs later in the warm simulation $S 1$ than in the reference simulation $S 0$ (Fig. 5a). The duration and termination of a bloom is controlled by both the nutrient availability and the temperature (Fig. $5 \mathrm{c}$ and d). Inversely, from January to April, the diatoms' growth limitation by temperature is strengthened in the warm simulation $S 1$ (Fig. $5 \mathrm{~h}$ ), because the resulting ambient temperature is further from the optimum temperature $\left(T_{\mathrm{opt}}=13^{\circ} \mathrm{C}\right.$, Table A4) than that in the reference simulation $S 0$. This induces a slower growth of diatoms and a delay of the maximum concentration (Fig. 5f). Afterwards the photosynthesis is mainly limited by temperature (Fig. 5h).

The ecosystem is dominated by autotrophs at the time of blooms whatever the simulation considered (NEP $>0$; Fig. 5e), and the quantity of DIC (not shown) fixed through autotrophic processes is larger than that released by heterotrophic processes. During the short period of a bloom, the seawater $p \mathrm{CO}_{2}$ decreases, leading to some negative airsea fluxes (i.e., an oceanic sink for atmospheric $\mathrm{CO}_{2}$ ). In the warm simulation, the later occurrence of a bloom enables the period of the spring sink to extend by ca. 3 weeks over May relative to the reference simulation (Fig. 5j).

\subsubsection{Wind speed}

The Bay of Marseille is periodically under the influence of strong wind events (Millot, 1990). Here we compare two simulations: one with a constant wind value $(S 2)$ and the other one with two wind events that occur in May and August (S3) (Fig. 6a and d). The result of this numerical experiment shows that the stronger the wind speed is, the higher the airsea fluxes are, mainly owing to the increase in gas transfer velocity. Depending on the gradient of $\mathrm{CO}_{2}$ between seawater and the atmosphere, strong wind speeds will favor either the emission or uptake of $\mathrm{CO}_{2}$ (Fig. $6 \mathrm{~b}$ and e). In May, with the air-sea $\mathrm{CO}_{2}$ flux being positive, the outgassing of $\mathrm{CO}_{2}$ to the atmosphere is enhanced, leading to a decrease in seawater $p \mathrm{CO}_{2}$ (Fig. 6c). On the contrary, in August the oceanic sink of atmospheric $\mathrm{CO}_{2}$ is amplified, which leads to an increase in the seawater $p \mathrm{CO}_{2}$ value (Fig. 6f).

\subsubsection{Supply in nitrate by river inputs}

According to the model results (Fig. 7), the occasional inputs of nitrate (S4) that are linked to Rhône River plume intrusions favor primary production, and they led to increased chlorophyll concentrations (Fig. 7b and c) five times during the SWC period. These blooms, as seen previously, lead to a decrease (increase) in the seawater $p \mathrm{CO}_{2}(\mathrm{pH})$ (Fig. 7e and $\mathrm{f}$ ). It can be noted that with the strongest river supply at mid-March (Fig. 7a and b) the occurrence of the spring bloom is earlier (Fig. 7c) than that occurring in the reference simulation $(S 0)$. The time lag between river nutrient supply and bloom is due to the temperature limitation (Fig. 4c). During blooms occurring within the SWC period following intrusions, the DIC concentrations are generally lower than those of the reference simulation, as in the case of the bloom of mid-May (decrease by ca. $15 \mu \mathrm{mol} \mathrm{kg}^{-1}$; Fig. 7j), due to the autotrophic processes dominating the heterotrophic ones. In turn, the seawater $p \mathrm{CO}_{2}$ drops by ca. $30 \mu \mathrm{atm}$ (Fig. $7 \mathrm{k}$ ) and $\mathrm{pH}$ increases by ca. 0.030 (Fig. 71). Nitrate inputs, favoring primary production, reduce the source of $\mathrm{CO}_{2}$ to the atmosphere and intensify the sink of atmospheric $\mathrm{CO}_{2}$ into the waters of BoM (Fig. 7e and k).

\subsubsection{Urban air $\mathrm{CO}_{2}$ concentrations}

The Aix-Marseille metropolis is strongly subject to urban emissions to the atmosphere (Xueref-Remy et al., 2018a). The seasonal variability of atmospheric $\mathrm{CO}_{2}$ concentrations at the urban site (CAV station; Fig. 2) is much higher than that observed in a non-urban area (OHP station; Fig. 2), especially during the MWC period (Fig. 8a): $\mathrm{CO}_{2}$ concentrations vary between 379 and $547 \mu \mathrm{atm}$ at the CAV station and between 381 and $429 \mu \mathrm{atm}$ at the OHP station. Moreover, in winter the atmospheric $p \mathrm{CO}_{2}$ is higher in the urban area than 

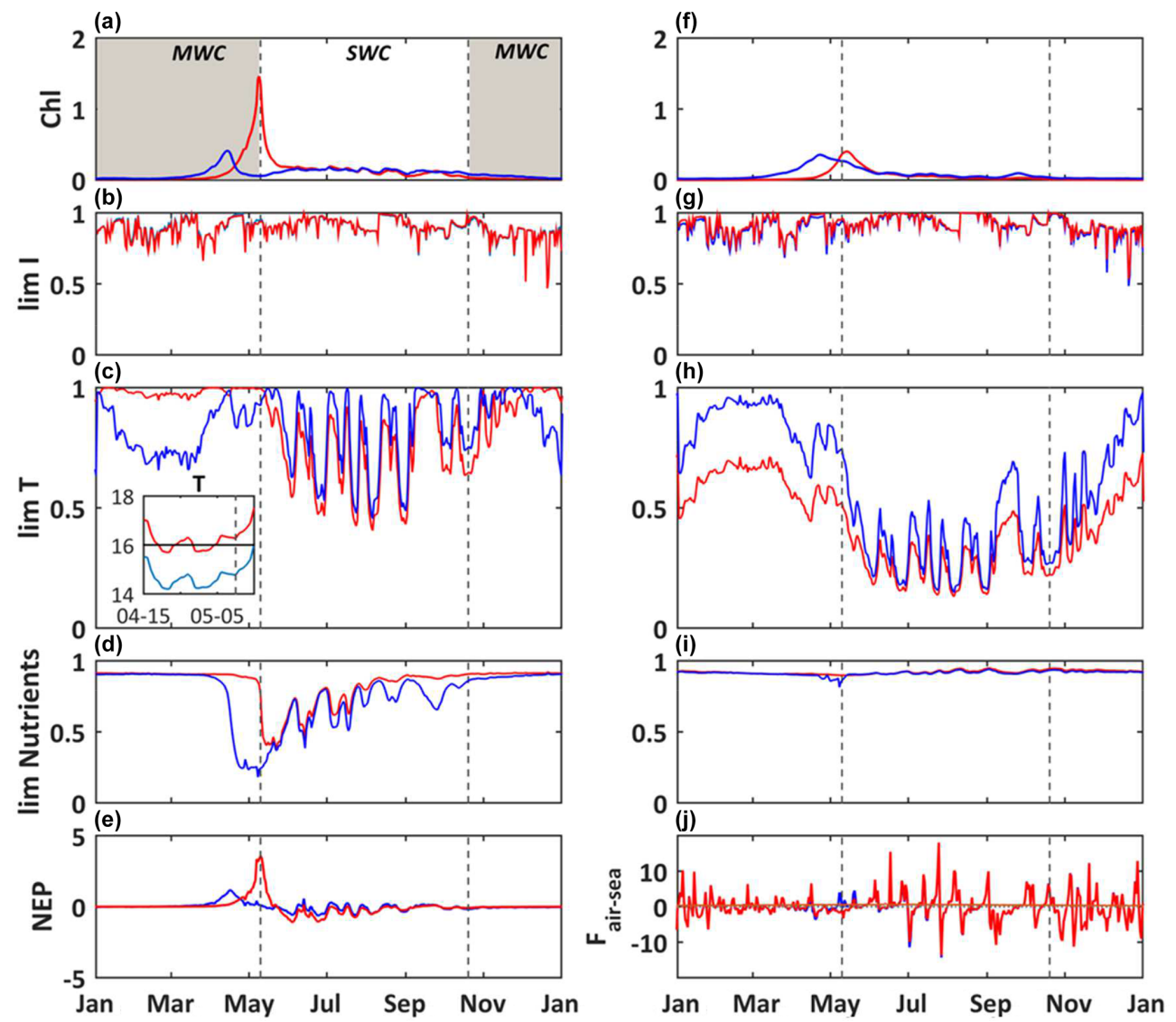

Figure 5. Modeled daily average chlorophyll $a$ concentrations $\left(\mathrm{mg} \mathrm{m}^{-3}\right)$ (a), light limitation (b), temperature limitation, and a close-up from 15 April to 5 May of temperature (c) and nutrient limitation (d) for picophytoplankton and the same set for diatoms (f-i). Modeled daily average NEP $\left(\mathrm{mmol} \mathrm{m}^{-3} \mathrm{~d}^{-1}, \mathbf{e}\right)$ and air-sea $\mathrm{CO}_{2}$ fluxes $\left(\mathrm{mmolm}^{-3} \mathrm{~d}^{-1}, \mathbf{j}\right)$. Reference simulation ( $\mathrm{S} 0$, blue line) and temperature-shifted simulation by $1.5^{\circ} \mathrm{C}(S 2$, red line). The shaded area and dotted black lines delimit the SWC and MWC periods.

the non-urban area, whereas in summer those of both areas are quite close. These differences in the seasonal pattern and between areas are usually explained by (i) the thinner atmospheric boundary layer, (ii) the decreased fixation of $\mathrm{CO}_{2}$ by terrestrial vegetation, and (iii) the greater influence of anthropogenic activities by emissions from heating (Xueref-Remy et al., 2018b). Forcing the model by atmospheric $\mathrm{pCO}_{2}$ values from urban or non-urban sites can lead to significant differences in the values of the seawater $p \mathrm{CO}_{2}$, especially during the $\mathrm{MWC}$ period. The air-sea gradient of $p \mathrm{CO}_{2}$ is higher when using a forcing derived from the $\mathrm{CO}_{2}$ concentrations originating from an urban area than from a non-urban area, which strengthens the sink of atmospheric $\mathrm{CO}_{2}$ into the waters of BoM. The seawater $p \mathrm{CO}_{2}$ is then lower with nonurban area pressure $(S 5)$ than with urban area pressure $(S 0)$, because of lower $\mathrm{CO}_{2}$ solubility in the BoM (Fig. 8b).

\section{Discussion}

\subsection{Model performance}

The evaluation of model skill vs. in situ data highlights that the modeled $\mathrm{pH}, p \mathrm{CO}_{2}$, and DIC are in acceptable agreement with observations (Fig. 3). The seasonal variations observed for the different variables are captured by the model, including for example the seasonal decrease in DIC and $\mathrm{pH}$ during the SWC period, in relation to the increase in $p \mathrm{CO}_{2}$, and the inverse scenario during the MWC period. The chlorophyll content variability is not well reproduced, especially during spring (Fig. 3a), even taking into account the nitrate supply from the Rhône River plume intrusion (Fig. 7c). This is due to the multiple origins of chlorophyll, organic matter, and nutrients in the BoM that are not accounted for in the Eco3M-CarbOx model: autochthonous marine production, and allochthonous origins from the Rhône and $\mathrm{Hu}-$ veaune River plumes (Fraysse et al., 2013). The observed variations and levels of TA are not correctly simulated by the model (Fig. 3f). The study of Soetaert et al. (2007) highlights 

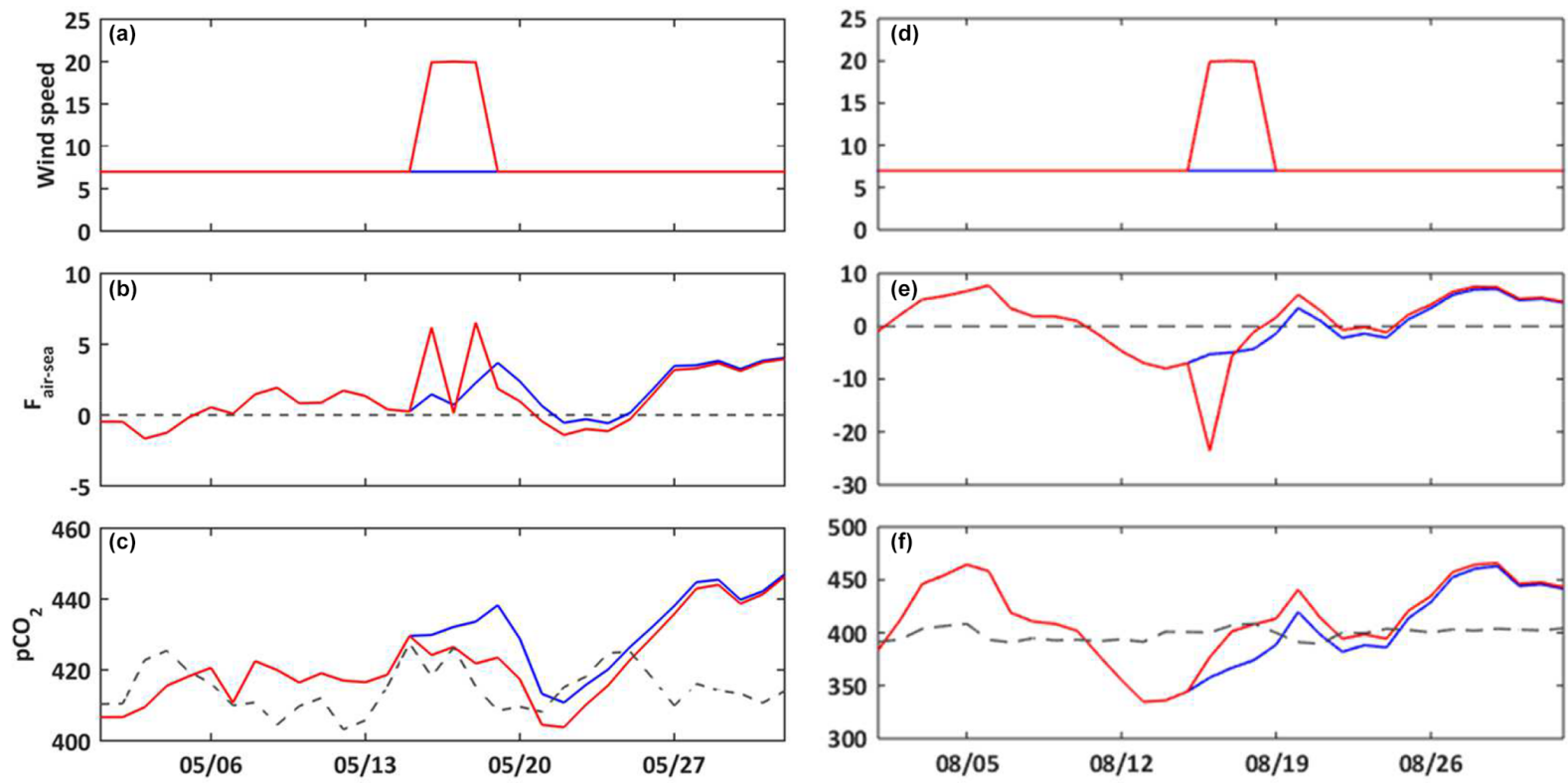

Figure 6. Temporal evolution for May (a-c) and August (d-f) 2017 of the wind speed ( $\left.\mathrm{ms}^{-1}, \mathbf{a}, \mathbf{d}\right)$; air-sea $\mathrm{CO}_{2}$ fluxes $\left(\mathrm{mmolm}^{-3} \mathrm{~d}^{-1}, \mathbf{b}\right.$, e); seawater $p \mathrm{CO}_{2}$ ( $\left.\mu \mathrm{atm}, \mathbf{c}, \mathbf{f}\right)$. Constant wind scenario ( $S 2$, blue line) and wind event scenario ( $S 3$, red line). On (c) and (f), the dashed line represents the atmosphere $p \mathrm{CO}_{2}(\mu \mathrm{atm})$ at the $\mathrm{CAV}$ station.

that the main variations of TA in the marine coastal zones are linked to freshwater supplies and marine sediments. The present study does not take into account the inputs of TA from the Rhône River and the water-sediment interface, and it may explain why the TA variable is not correctly predicted by our model.

\subsection{Contribution of physical and biogeochemical processes to the variability of carbonate system}

The contribution of each biogeochemical process to the DIC variability can be assessed using the presented model: the aeration process contributes to $78 \%$ of the DIC variations, and all biogeochemical processes together contribute to $22 \%$ (Table 3). As mentioned by Wimart-Rousseau et al. (2020), the model suggests that the seawater $p \mathrm{CO}_{2}$ variations and associated fluxes would be mostly driven by the seawater temperature dynamics. Moreover, the seasonal variations of the air-sea $\mathrm{CO}_{2}$ flux are in agreement with some previous field studies (De Carlo et al., 2013; Wimart-Rousseau et al., 2020), which measured a weak oceanic sink for atmospheric $\mathrm{CO}_{2}$ during winter and a weak source to the atmosphere during summer.

The model results reveal that temperature would play a crucial role in controlling two counterbalanced processes: (1) the carbonate system equilibrium and (2) the phytoplankton growth. The increase in temperature during SWC leads to a higher $p \mathrm{CO}_{2}$ in seawater due to the decrease in the $\mathrm{CO}_{2}$ solubility (Middelburg, 2019) and, at the same time, the fixation of DIC by phytoplankton is favored, leading to a de- crease in the $p \mathrm{CO}_{2}$ level. The imbalance between the latter two processes leads to a change in the ecosystem status (autotrophic or heterotrophic) and the corresponding behavior as a sink or source to the atmosphere. In case of a $1.5^{\circ} \mathrm{C}$ rise over the whole year, the temperature variation has a very small impact on the carbonate system dynamics. However, it favors the autotrophic processes and strengthens the oceanic sink of atmospheric $\mathrm{CO}_{2}$ during the bloom of phytoplankton (Fig. 5e and j).

\subsection{Contribution of the external forcing to the variability of carbonate system}

In line with several previous works on the northwestern Mediterranean Sea (De Carlo et al., 2013; Copin-Montégut et al., 2004; Wimart-Rousseau et al., 2020), the model also suggests that the status of the Bay of Marseille regarding sink or source for $\mathrm{CO}_{2}$ could change at high temporal frequency (i.e., hours to days). Bursts of north-northwestern winds lead to sudden and sharp decreases in seawater temperature $(<2 \mathrm{~d}$; Fig. $4 \mathrm{~g})$ either directly by latent heat loss through evaporation at the surface (Herrmann et al., 2011) or indirectly by creating upwelling (Millot, 1990), with the consequences of a decrease in the seawater $p \mathrm{CO}_{2}$ values (Fig. 4j) and, in fine, an alteration of the $\mathrm{CO}_{2}$ air-sea fluxes. Model results suggest that the fast variations of temperature could lead to rapid changes of the sink vs. source status in this coastal zone (Fig. 4k). Moreover, Fraysse et al. (2013) highlight that upwelling in the BoM favors ephemeral blooms of phytoplankton by nutrient supplies up to the eu- 

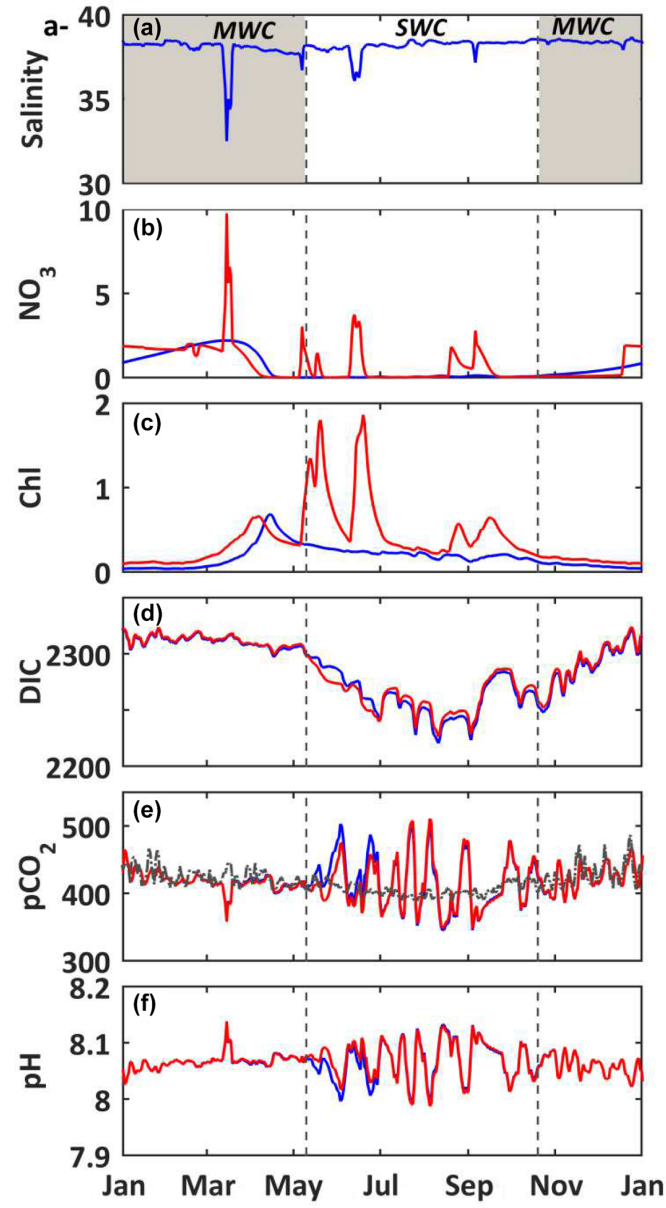
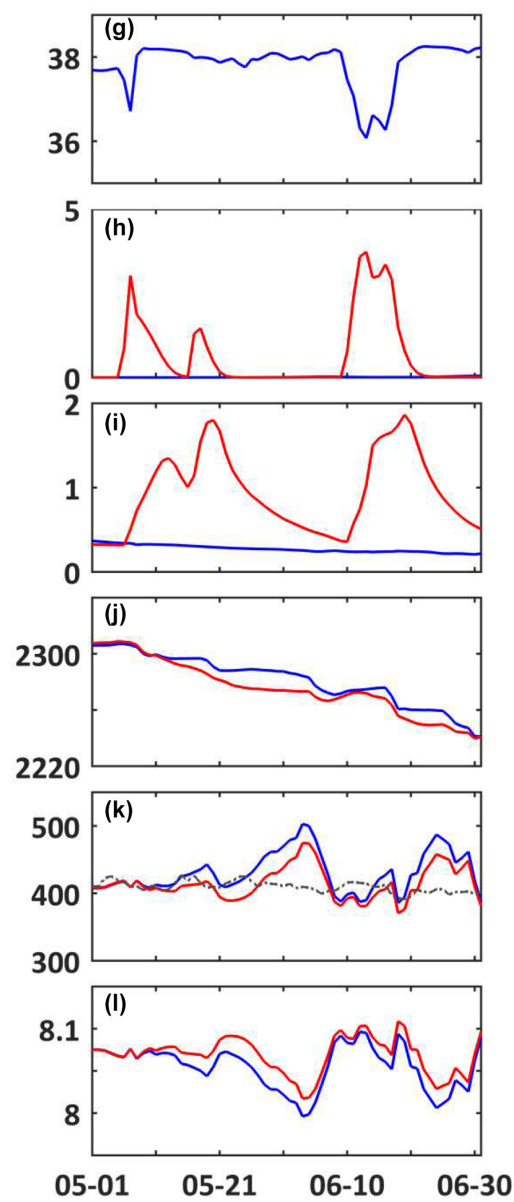

Figure 7. (a-f) 2017. (g-l) Temporal focus between 1 May and 1 July 2017. (a, g) In situ daily average of salinity. Modeled daily average (b, h) nitrate concentrations $\left(\mathrm{mmol} \mathrm{m}^{-3}\right)$; $(\mathbf{c}, \mathbf{i})$ chlorophyll $a$ concentrations $\left(\mathrm{mg} \mathrm{m}^{-3}\right) ;(\mathbf{d}, \mathbf{j}) \mathrm{DIC}(\mu \mathrm{mol} \mathrm{kg}-1)$; $(\mathbf{e}, \mathbf{k}) \mathrm{seawater} \mathrm{COO}_{2}(\mu \mathrm{atm})$; and (f, l) $\mathrm{pH}$. Reference simulation ( $S 0$, blue line) and nitrate supply simulation ( $S 4$, red line). On (e) and (k), the dashed line represents the atmosphere $p \mathrm{CO}_{2}$ ( $\left.\mu \mathrm{atm}\right)$ at the CAV station. The shaded area and dotted black lines delimit the SWC and MWC periods.

photic layer and would, in turn, contribute to the seawater $p \mathrm{CO}_{2}$ decrease. North and northwestern winds through latent heat losses and/or upwelling events could then enhance the sink for atmospheric $\mathrm{CO}_{2}$ due to the temperature drop and nutrients inputs. However, these results remain preliminary because in our experimental design only the cooling effect of upwelling on the carbonate balance is taken into account. But concomitantly, upwelling usually bring nutrients and DIC at the surface and these supplies could also perturb the balance of the carbonate system. A further coupling of the Eco3M-CarbOx model with a tridimensional hydrodynamic model would certainly enable the multiple effects of upwelling on the dynamics of the carbonate system in this area to be embraced and the results presented in this study to be refined.

High wind speeds $\left(>7 \mathrm{~m} \mathrm{~s}^{-1}\right)$ amplified the gaseous exchange of $\mathrm{CO}_{2}$ considerably (De Carlo et al., 2013; CopinMontégut et al., 2004; Wimart-Rousseau et al., 2020). The model highlights that a strong wind event of $3 \mathrm{~d}$ has a sig- nificant impact on the seawater $p \mathrm{CO}_{2}$ values during a longer period of ca. $15 \mathrm{~d}$ (Fig. 6). A combination of high atmospheric $p \mathrm{CO}_{2}$ values and high wind speeds would then favor the sink for $\mathrm{CO}_{2}$ into the waters of the BoM. The aeration process also depends on the choice of the formulation of the gas transfer velocity $\left(k_{600}\right)$. In this study, the formulation of Wanninkhof (1992) is used and depends of the wind speed at $10 \mathrm{~m}$ above the water surface. However, the current velocity could favor the gas exchange, and suspended matter concentration could limit the gas exchange (Abril et al., 2009; Upstill-Goddard, 2006; Zappa et al., 2003). Due to the important heterogeneity of physical and biogeochemical forcings in coastal zones, other factors that control the air-sea gas exchange should certainly be taken into account.

The simulation with intrusions of the Rhône River plume shows that inputs of nitrate cause a drop of seawater $p \mathrm{CO}_{2}$ owing to the nutrient supply favoring the phytoplankton development (Fig. 7). In this scenario, the oceanic sink of atmospheric $\mathrm{CO}_{2}$ is enhanced. But rivers also supply TA (e.g., 

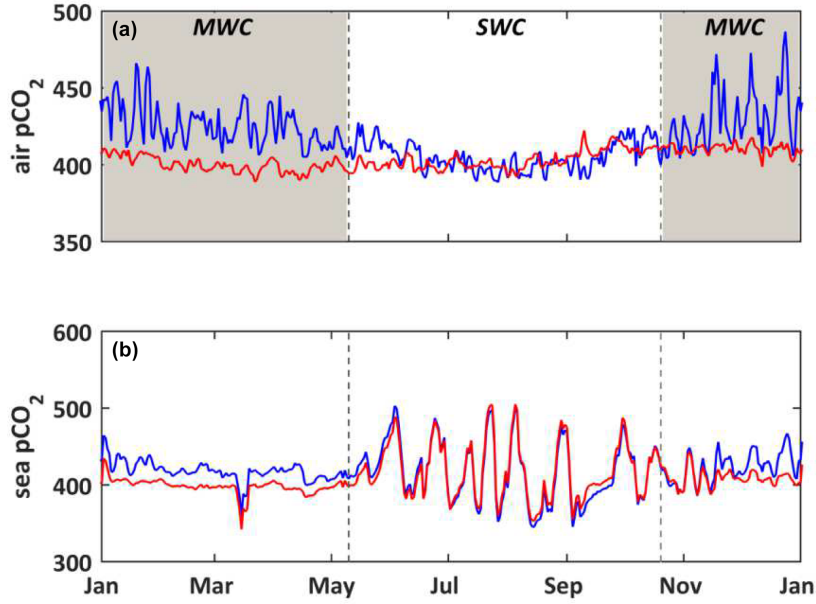

Figure 8. (a) Temporal evolution for the year 2017 of the observed $p \mathrm{CO}_{2}$ ( $\left.\mu \mathrm{atm}\right)$ in the atmosphere at the CAV station, called the "urban scenario" ( $S 0$, blue line), and at the OHP station, called the "non-urban scenario" ( $S 6$, red line). (b) Temporal evolution for the year 2017 of the modeled seawater $p \mathrm{CO}_{2}$ ( $\mu$ atm) with forcings from the urban ( $S 0$, blue line) and non-urban (S6, red line) scenarios. The shaded area and dotted black lines delimit the SWC and MWC periods.

Gemayel et al., 2015; Schneider et al., 2007) and DIC (e.g., Sempéré et al., 2000) that shift the carbonate system equilibrium toward a $p \mathrm{CO}_{2}$ decrease and a DIC increase (Middelburg, 2019). Taking into account these further supplies may sensibly modify the modeled carbonate balance in the BoM. A next step to the present work will be to design more realistic numerical experiments to refine the results obtained in this preliminary study. The intrusions of the Rhône River plume also induce a salinity decrease in the BoM waters, which leads to a drop in the $p \mathrm{CO}_{2}$ levels in the model. This drop of $p \mathrm{CO}_{2}$ is due to the decrease in the $\mathrm{CO}_{2}$ solubility when salinity decreases (Middelburg, 2019).

In the scenario of forcing the model by using urban atmospheric $p \mathrm{CO}_{2}$ time series, the air-sea gradient increases, and then it enhances the status of the BoM as a sink for atmospheric $\mathrm{CO}_{2}$. As suggested by the in situ study of WimartRousseau et al. (2020), the Eco3M-Carbox model highlights the crucial role of the coastal ocean in an urbanized area, and with an increase in atmospheric $\mathrm{CO}_{2}$, the $\mathrm{CO}_{2}$ uptake by the coastal ocean may increase. This result is in line with the studies of Andersson and Mackenzie (2004) and Cai (2011), which predict an increase in the intensity of the $\mathrm{CO}_{2}$ sink and a potential threat to coastal marine biodiversity in coastal areas owing to high atmospheric $\mathrm{CO}_{2}$ levels.

\section{Conclusions}

A marine carbonate chemistry module was implemented in the Eco3M-CarbOx biogeochemical model and evaluated against in situ data available in the Bay of Marseille (northwestern Mediterranean Sea) over the year 2017. The model correctly simulates the value ranges and seasonal dynamics of most of the variables of the carbonate system except for the total alkalinity. Several numerical experiments were also conducted to test the sensitivity of the carbon balance to physical processes (temperature and salinity), biogeochemical processes (GPP and respiration processes), and external forcing (wind, river intrusion, and atmospheric $\mathrm{CO}_{2}$ ). This set of numerical experiments shows that the Eco3M-CarbOx model provides expected responses in the alteration of the marine carbonate balance regarding each of the considered perturbation.

On the whole, the model results suggest that the carbonate system is mainly driven by the seawater temperature dynamics. At a seasonal scale, the BoM marine waters appear to be a net sink of atmospheric $\mathrm{CO}_{2}$ and a dominantly autotrophic ecosystem during the MWC period, and a net source of $\mathrm{CO}_{2}$ to the atmosphere during the SWC period, which is mainly characterized by a dominance of heterotrophic processes. However, the model results highlight that sharp seawater cooling observed within the SWC period, probably owing to upwelling events, cause the $\mathrm{CO}_{2}$ status of the BoM marine waters to change from a source to the atmosphere to a sink into the ocean within a few days. External forcing as the temperature increases leads to a delay in the bloom of phytoplankton. Strong wind events enhance the gas exchange of $\mathrm{CO}_{2}$ with the atmosphere. A Rhône River plume intrusion with input of nitrate favors $p \mathrm{CO}_{2}$ decreases, and the sink of atmospheric $\mathrm{CO}_{2}$ into the $\mathrm{BoM}$ waters is enhanced. The higher atmospheric $p \mathrm{CO}_{2}$ values from the urban area intensify the oceanic sink of atmospheric $\mathrm{CO}_{2}$.

The BoM biogeochemical functioning is mainly forced by wind-driven hydrodynamics (upwelling, downwelling), urban rivers, wastewater treatment plants, and atmospheric deposition (Fraysse et al., 2013). In addition, Northern Current and Rhône River plume intrusions frequently occurred (Fraysse et al., 2014; Ross et al., 2016). Moreover, the BoM harbors the second biggest metropolis of France (Marseille), which is impacted by many harbor activities. The next step of this study will be to couple the Eco3M-CarbOx biogeochemical model to a 3-D hydrodynamic model that will mirror the complexity of the BoM functioning. In this way, the contributions of hydrodynamic, atmospheric, anthropic, and biogeochemical processes to the DIC variability will be able to be determined with higher refinement and realism, and an overview of the air-sea $\mathrm{CO}_{2}$ exchange could be made at the scale of the Bay of Marseille. The main results of our study could be transposed to other coastal sites that are also impacted by urban and anthropic pressures. Moreover, in this paper we highlighted that fast and strong variations of $p \mathrm{CO}_{2}$ values occur, and thus it is essential to acquire more in situ values at high frequency (at least with an hourly resolution) to understand the rapid variations of the marine carbon system at these short spatial and temporal scales. 
Appendix A: Details of resolution of carbonate system module

\section{A1 Calculation of carbonate system constants}

The concentrations in conservative elements (relative to salinity) are calculated as follows:

- Total fluoride (TF) concentrations from Riley (1965) in $\mathrm{mol} \mathrm{kg}^{-1}$ :

$$
\mathrm{TF}=\frac{0.000067}{18.998} \cdot \frac{S}{1.80655}
$$

- Total sulfate (TS) concentration from Morris and Riley (1966) in $\mathrm{mol} \mathrm{kg}^{-1}$ :

$$
\mathrm{TS}=\frac{0.14}{96.062} \cdot \frac{S}{1.80655}
$$

- Calcium ion concentration from Riley and Tongudai (1967) in $\mathrm{mol} \mathrm{kg}^{-1}$ :

$$
\mathrm{Ca}^{2+}=\frac{0.02128}{40.087} \cdot \frac{S}{1.80655}
$$

- Total boron (TB) concentration from Uppström (1974) in $\mathrm{mol} \mathrm{kg}^{-1}$ :

$$
\mathrm{TB}=\frac{0.000416 \cdot S}{35} \text {. }
$$

- Ionic strength (IonS) from Millero (1982):

$$
\text { IonS }=\frac{19.924 \cdot S}{1000-1.005 \cdot S}
$$

The constants are calculated on the total $\mathrm{pH}$ scale except for $K_{S}$ on free $\mathrm{pH}$ scale. If necessary, $\mathrm{pH}$ scale conversion factors are as follows:

- From seawater $\mathrm{pH}$ scale (SWS) to total $\mathrm{pH}$ scale: $\mathrm{SWStoTOT}=\frac{1+\frac{\mathrm{TS}}{K_{S}}}{1+\frac{\mathrm{TS}}{K_{S}}+\frac{\mathrm{TF}}{K_{F}}} ;$

- From free $\mathrm{pH}$ scale to total $\mathrm{pH}$ scale: FREEtoTOT $=$ $1+\frac{\mathrm{TS}}{K_{S}}$.

Further carbonate system constants were calculated as follows:

- $K_{S}$ equilibrium constant of dissociation of $\mathrm{HSO}_{4}^{-}$from Dickson (1990a) in mol kg-1.

$$
\begin{aligned}
K_{S}= & \frac{-4276.1}{T_{(K)}}+141.328-23.093 \cdot \log \left(T_{(K)}\right) \\
& +\left(324.57-47.986 \cdot \log \left(T_{(K)}\right)-\frac{13856}{T_{(K)}}\right) \\
& \cdot \text { Ions }^{2}, \\
K_{S}= & K_{S}+\left(-771.54+114.723 \cdot \log \left(T_{(K)}\right)\right. \\
& \left.+\frac{35474}{T_{(K)}}\right) \cdot \text { Ions }+\frac{-2698}{T_{(K)}} \cdot \operatorname{Ions} \frac{3}{2}+\frac{1776}{T_{(K)}} \\
& \cdot \text { Ions }^{2}, \\
K_{S}= & e^{K_{S} \cdot(1-0.001005 \cdot S)} ;
\end{aligned}
$$

- $K_{\mathrm{F}}$ equilibrium constant of dissociation of hydrogen fluoride (HF) formation from Dickson and Riley (1979) in $\mathrm{mol} \mathrm{kg}^{-1}$ :

$$
K_{\mathrm{F}}=e^{\frac{1590.2}{T_{(K)}}-12.641+1.525 \cdot \operatorname{Ions}^{\frac{1}{2}}} \cdot(1-0.001005 \cdot S)
$$

- $K_{\mathrm{B}}$ equilibrium constant of dissociation of boric acid from Dickson (1990b) in $\mathrm{mol} \mathrm{kg}^{-1}$ :

$$
\begin{aligned}
K_{\mathrm{B}}= & \left(-8966.9-2890.53 \cdot S^{\frac{1}{2}}-77.942 \cdot S\right. \\
& \left.+1.728 \cdot S^{\frac{3}{2}}-0.0996 \cdot S^{2}\right) / T_{(K)}, \\
K_{\mathrm{B}}= & K_{\mathrm{B}}+148.0248+137.1942 \cdot S^{\frac{1}{2}}+1.62142 \cdot S \\
& +\left(-24.4344-25.085 \cdot S^{\frac{1}{2}}-0.2474 \cdot S\right) \\
& \cdot \log (T)+0.053105 \cdot S^{\frac{1}{2}} \cdot T
\end{aligned}
$$

- $K_{0}$ constant of $\mathrm{CO}_{2}$ solubility from Weiss (1974) in $\mathrm{mol} \mathrm{kg}^{-1} \mathrm{~atm}^{-1}$ :

$$
\begin{aligned}
K_{0}= & \exp \left(-60.2409+93.4517 \cdot \frac{100}{T_{(K)}}+23.3585\right. \\
& \cdot \log \left(\frac{T_{(K)}}{100}\right)+S \cdot\left(0.023517-0.023656 \cdot \frac{T_{(K)}}{100}\right. \\
& \left.\left.+0.0047036 \cdot\left(\frac{T_{(K)}}{100}\right)^{2}\right)\right)
\end{aligned}
$$

- $K_{e}$ dissociation constant of water from Millero (1995) in $\left(\mathrm{mol} \mathrm{kg}^{-1}\right)^{2}$ :

$$
\begin{aligned}
K_{e}= & \exp \left(\frac{-13847.26}{T_{(K)}}+148.9802-23.6521\right. \\
& \cdot \log \left(T_{(K)}\right)+\left(-5.977+\frac{118.67}{T_{(K)}}+1.0495\right. \\
& \left.\left.\cdot \log \left(T_{(K)}\right)\right) \cdot S^{\frac{1}{2}}-0.01615 \cdot S\right) \\
K_{e}= & K_{e} \cdot \text { SWStoTOT, on total } p \mathrm{H} \text { scale in mol kg }
\end{aligned}
$$


- $K_{1}$ and $K_{2}$ from Lueker et al. (2000) in mol kg ${ }^{-1}$ :

$$
\begin{aligned}
& K_{1}=10\left(\begin{array}{l}
\frac{-3633.86}{T_{(K)}}+61.2172-9.6777 \cdot \log \left(T_{(K)}\right) \\
+0.011555 \cdot S-0.0001152 \cdot S^{2}
\end{array}\right), \\
& K_{2}=10\left(\begin{array}{l}
\frac{-471.78}{T_{(K)}}+251.929-3.16967 \cdot \log \left(T_{(K)}\right) \\
+0.01781 \cdot S-0.0001122 \cdot S^{2}
\end{array}\right) ;
\end{aligned}
$$

- $K_{\mathrm{ca}}$ for calcite from Mucci (1983) in $\left(\mathrm{mol} \mathrm{kg}^{-1}\right)^{2}$ :

$$
K_{\mathrm{ca}}=10\left(\begin{array}{l}
-171.9065-0.077993 \cdot T_{(K)}+\frac{2839.319}{T_{(K)}} \\
+71.595 \cdot \log 10\left(T_{(K)}\right)+(-0.77712 \\
\left.+0.0028426 \cdot T_{(K)}\right)+\frac{178.34}{T_{(K)}} \cdot S^{\frac{1}{2}} \\
-0.07711 \cdot S \\
+0.0041249 \cdot S^{\frac{3}{2}}
\end{array}\right) .
$$

All the constants are corrected by the effect of hydrostatic pressure:

$$
R=83.1451 \text { in } \mathrm{ml} \mathrm{bar}^{-1} \mathrm{~K}^{-1} \mathrm{~mol}^{-1} ;
$$

$$
\begin{aligned}
& \left(25.5-0.1271 \cdot T_{\left({ }^{\circ} \mathrm{C}\right)}+0.5\right. \\
& \ln K_{1} \mathrm{fac}=\frac{\left.\cdot\left(\frac{-3.08+0.0877 \cdot T_{\left({ }^{\circ} \mathrm{C}\right)}}{1000}\right) \cdot P_{\mathrm{bar}}\right) \cdot P_{\mathrm{bar}}}{R \cdot T_{(K)}}, \\
& K_{1}=K_{1} \cdot e^{\ln K_{1} \mathrm{fac}} ; \\
& \left(15.82-0.0219 \cdot T_{\left({ }^{\circ} \mathrm{C}\right)}+0.5\right. \\
& \ln K_{2} \mathrm{fac}=\frac{\left.\cdot\left(\frac{1.13+0.1475 \cdot T_{\left({ }^{\circ} \mathrm{C}\right)}}{1000}\right) \cdot P_{\mathrm{bar}}\right) \cdot P_{\mathrm{bar}}}{R \cdot T_{(K)}}, \\
& K_{2}=K_{2} \cdot e^{\ln K_{2} \mathrm{fac}} ; \\
& \left(29.48-0.1622 \cdot T_{\left({ }^{\circ} \mathrm{C}\right)}+0.002608\right. \\
& \ln K_{\mathrm{B}} \mathrm{fac}=\frac{\left.\cdot T^{\left({ }^{\circ} \mathrm{C}\right)}+0.5 \cdot\left(\frac{-2.84}{1000}\right) \cdot P_{\mathrm{bar}}\right) \cdot P_{\mathrm{bar}}}{R \cdot T_{(K)}}, \\
& K_{\mathrm{B}}=K_{\mathrm{B}} \cdot e^{\ln K_{\mathrm{B}} \mathrm{fac}} ; \\
& \left(20.02-0.1119 \cdot T_{\left({ }^{\circ} \mathrm{C}\right)}+0.001409\right. \\
& \left.\cdot T_{\left({ }^{\circ} \mathrm{C}\right)}^{2}+0.5 \cdot\left(\frac{-5.13+0.0794 \cdot T_{\left({ }^{\circ} \mathrm{C}\right)}}{1000}\right) \cdot P_{\mathrm{bar}}\right) \\
& \ln K_{e} \mathrm{fac}=\frac{\cdot P_{\mathrm{bar}}}{R \cdot T_{(K)}} \\
& K_{e}=K_{e} \cdot e^{\ln K_{e} \mathrm{fac}}
\end{aligned}
$$

$$
\begin{aligned}
& \left(9.78-0.009 \cdot T_{\left({ }^{\circ} \mathrm{C}\right)}+0.0009429\right. \\
& \left.\cdot T_{\left({ }^{\circ} \mathrm{C}\right)}^{2}+0.5 \cdot\left(\frac{-3.91+0.054 \cdot T_{\left({ }^{\circ} \mathrm{C}\right)}}{1000}\right) \cdot P_{\mathrm{bar}}\right) \\
& \ln K_{\mathrm{F}} \mathrm{fac}=\frac{\cdot P_{\mathrm{bar}}}{R \cdot T_{(K)}}, \\
& K_{\mathrm{F}}=K_{\mathrm{F}} \cdot e^{\ln K_{\mathrm{F}} \mathrm{fac}} \\
& \left(18.03-0.0466 \cdot T_{\left({ }^{\circ} \mathrm{C}\right)}+0.000316\right. \\
& \left.\cdot T_{\left({ }^{\circ} \mathrm{C}\right)}^{2}+0.5 \cdot\left(\frac{-4.53+0.009 \cdot T_{\left({ }^{\circ} \mathrm{C}\right)}}{1000}\right) \cdot P_{\mathrm{bar}}\right) \\
& \ln K_{S} \mathrm{fac}=\frac{\cdot P_{\mathrm{bar}}}{R \cdot T_{(K)}}, \\
& K_{S}=K_{S} \cdot e^{\ln K_{S} \mathrm{fac}} . \\
& \left(48.76-0.5304 \cdot T_{\left({ }^{\circ} \mathrm{C}\right)}\right. \\
& \ln K_{\mathrm{ca}} \mathrm{fac}=\frac{\left.+0.5 \cdot\left(\frac{-11.76+0.3692 \cdot T_{\left({ }^{\circ} \mathrm{C}\right)}}{1000}\right) \cdot P_{\mathrm{bar}}\right) \cdot P_{\mathrm{bar}}}{R \cdot T_{(K)}} ; \\
& K_{\mathrm{ca}}=K_{\mathrm{ca}} \cdot e^{\ln K_{\mathrm{ca}} \mathrm{fac}}
\end{aligned}
$$

\section{Calculation of the fugacity factor}

We suppose that the pressure is at one atmosphere or close to it (Weiss, 1974):

$P_{\mathrm{atm}}=1.01325 \mathrm{bar}$,

delta $=57.7-0.118 \cdot T$ in $\mathrm{cm}^{3} \mathrm{~mol}^{-1}$,

$b=-1636.75+12.0408 \cdot T-0.0327957 \cdot T^{2}$,

$$
+3.16528 \cdot 0.00001 \cdot T^{3} \text { in } \mathrm{cm}^{3} \mathrm{~mol}^{-1},
$$

FugFac $=\exp ^{\frac{(b+2 \cdot \text { delta) })}{R \cdot T} \text { atm }}$. 


\section{A2 Resolution of carbonate system}

To resolve the carbonate system, we calculate the deltapH, which is the difference of $\mathrm{pH}$ between two iterations of the model. We initialize the run by imposing a $\mathrm{pH}$ value of 8 .

$$
\begin{aligned}
& \mathrm{CO}_{3}=\frac{K_{2} \cdot \mathrm{HCO}_{3}}{H} \\
& \text { Omega }=\frac{\mathrm{Ca} \cdot \mathrm{CO}_{3} \cdot 10^{-6}}{K_{\mathrm{ca}}}
\end{aligned}
$$

if $($ nbiter $<1) \mathrm{pH}=8$

$\mathrm{pHtol}=0.001 \quad$ ! tolerance for iterations end

deltapH $=\mathrm{pHtol}+1$

do while $(\operatorname{abs}(\operatorname{deltapH})>0.0001)$

$$
\begin{aligned}
& H=10^{-\mathrm{pH}} \\
& \text { Denom }=H^{2}+K_{1} \cdot H+K_{1} \cdot K_{2} \\
& \mathrm{CAlk}=\mathrm{DIC} \cdot K_{1} \cdot\left(\frac{H+2 \cdot K_{2}}{\text { Denom }}\right) \\
& \mathrm{BAlk}=\frac{\mathrm{TB} \cdot K_{\mathrm{B}}}{K_{\mathrm{B}}+H} \\
& \mathrm{OH}=\frac{K_{e}}{H} \\
& \text { FreetoTot }=1+\frac{\mathrm{TS}}{K_{S}} \\
& \text { Hfree }=\frac{H}{\text { FreetoTot }} \\
& \mathrm{HSO}_{4}=\frac{\mathrm{TS}}{1+\frac{K_{S}}{\text { Hfree }}} \\
& \mathrm{HF}=\frac{\mathrm{TF}}{1+\frac{K_{\mathrm{F}}}{\text { Hfree }}} \\
& \text { Residual }=\mathrm{TA}-\mathrm{CAlk}-\mathrm{BAlk}-\mathrm{OH}+\mathrm{Hfree}+\mathrm{HSO}_{4} \\
& +\mathrm{HF} \\
& \text { Slope }=\mathrm{DIC} \cdot H \cdot K_{1} \cdot\left(H^{2}+K_{1} \cdot K_{2}+4 \cdot H \cdot K_{2}\right) \\
& \text { Slope }=\frac{\text { Slope }}{\text { Denom }^{2}}+\mathrm{OH}+H+\frac{\mathrm{BAlk} \cdot H}{K_{\mathrm{B}}+H} \\
& \text { Slope }=\log 10 \cdot \text { Slope } \\
& \text { deltapH }=\text { Residual/Slope } \quad \text { ! this is Newton's method } \\
& \text { do while }(\operatorname{abs}(\operatorname{deltap} H)>1) \text { deltapH }=\frac{\operatorname{deltapH}}{2} \\
& \text { ! to keep the jump from being too big }
\end{aligned}
$$

enddo

$\mathrm{pH}=\mathrm{pH}+$ deltapH $\quad$ ! Is on the same scale as $K_{1}$ and $K_{2}$

were calculated, i.e., total $p \mathrm{H}$ scale

$p \mathrm{CO}_{2}=\left(\frac{\mathrm{DIC} \cdot H^{2}}{H^{2}+K_{1} \cdot H+K_{1} \cdot K_{2}}\right) \cdot \frac{10^{6}}{K_{0} \cdot \text { FugFac }}$

$$
\text { ! in } \mu \text { atm }
$$

$\mathrm{CO}_{2}=\frac{\mathrm{DIC} \cdot 10^{6}}{1+\frac{K_{1}}{H}+\frac{K_{1} \cdot K_{2}}{H^{2}}}$

$\mathrm{HCO}_{3}=\frac{K_{1} \cdot \mathrm{CO}_{2}}{H}$ 
Appendix B: Biogeochemical model variables and

parameters

Table B1. Initial conditions of the state variables of the Eco3M-CarbOx model.

\begin{tabular}{|c|c|c|c|}
\hline Variables & Name & Unit & Values \\
\hline Picophytoplankton & $\begin{array}{l}\text { PicoC } \\
\text { PicoN } \\
\text { PicoP }\end{array}$ & $\begin{array}{l}\mathrm{mmolCm}^{-3} \\
\mathrm{mmolNm}^{-3} \\
\mathrm{mmolPm}^{-3}\end{array}$ & $\begin{array}{l}0.0480 \\
0.0092 \\
0.0003\end{array}$ \\
\hline Diatom & $\begin{array}{l}\text { DiaC } \\
\text { DiaN } \\
\text { DiaP }\end{array}$ & $\begin{array}{l}\mathrm{mmolCm}^{-3} \\
\mathrm{mmol} \mathrm{Nm}^{-3} \\
\mathrm{mmolPm}^{-3}\end{array}$ & $\begin{array}{l}0.0571 \\
0.0089 \\
0.0007\end{array}$ \\
\hline Bacteria & $\begin{array}{l}\mathrm{BacC} \\
\mathrm{BacN} \\
\mathrm{BacP}\end{array}$ & $\begin{array}{l}\mathrm{mmolCm}^{-3} \\
\mathrm{mmolNm}^{-3} \\
\mathrm{mmolPm}^{-3}\end{array}$ & $\begin{array}{l}0.1083 \\
0.0379 \\
0.0039\end{array}$ \\
\hline $\begin{array}{l}\text { DPOM } \\
\text { Detrital particulate organic matter }\end{array}$ & $\begin{array}{l}\text { DPOC } \\
\text { DPON } \\
\text { DPOP }\end{array}$ & $\begin{array}{l}\mathrm{mmol} \mathrm{Cm}^{-3} \\
\mathrm{mmol} \mathrm{Nm}^{-3} \\
\mathrm{mmol} \mathrm{Pm}^{-3}\end{array}$ & $\begin{array}{l}0.1252 \\
0.0307 \\
0.0021\end{array}$ \\
\hline $\begin{array}{l}\text { LDOM } \\
\text { Labile dissolved organic matter }\end{array}$ & $\begin{array}{l}\text { LDOC } \\
\text { LDON } \\
\text { LDOP }\end{array}$ & $\begin{array}{l}\mathrm{mmolCm}^{-3} \\
\mathrm{mmolNm}^{-3} \\
\mathrm{mmolPm}^{-3}\end{array}$ & $\begin{array}{l}1.0990 \\
8.7980 \\
0.0018\end{array}$ \\
\hline $\begin{array}{l}\text { DIM } \\
\text { Dissolved inorganic matter }\end{array}$ & $\begin{array}{l}\mathrm{NH}_{4} \\
\mathrm{NO}_{3} \\
\mathrm{PO}_{4} \\
\mathrm{DO} \\
\mathrm{DIC}\end{array}$ & $\begin{array}{l}\mathrm{mmol} \mathrm{N} \mathrm{m}^{-3} \\
\mathrm{mmol} \mathrm{N} \mathrm{m}^{-3} \\
\mathrm{mmol} \mathrm{Pm}^{-3} \\
\mathrm{mmol} \mathrm{Om}^{-3} \\
\mu \mathrm{mol} \mathrm{kg}^{-1}\end{array}$ & $\begin{array}{l}0.3375 \\
0.6723 \\
0.7150 \\
257.00 \\
2358.4\end{array}$ \\
\hline $\begin{array}{l}\text { Total alkalinity } \\
\text { Sea water partial pressure of } \mathrm{CO}_{2} \\
\text { pH } \\
\text { calcium carbonate }\end{array}$ & $\begin{array}{l}\mathrm{TA} \\
p \mathrm{CO}_{2} \\
\mathrm{pH} \\
\mathrm{CaCO}_{3}\end{array}$ & $\begin{array}{l}\mu \mathrm{molC \textrm {kg } ^ { - 1 }} \\
\mu \mathrm{atm} \\
- \\
\mathrm{mmol} \mathrm{m}^{-3}\end{array}$ & $\begin{array}{l}2660.5 \\
371.28 \\
8.1099 \\
1.0000\end{array}$ \\
\hline $\begin{array}{l}\text { Picophytoplankton chlorophyll* } \\
\text { Diatom chlorophyll* } \\
\text { Number of bacteria* }\end{array}$ & $\begin{array}{l}\text { PicoChl } \\
\text { DiaChl } \\
\text { NBA }\end{array}$ & $\begin{array}{l}\mathrm{mgChl} \mathrm{m}^{-3} \\
\mathrm{mgChl} \mathrm{m}^{-3} \\
10^{12} \text { cell m}^{-3}\end{array}$ & $\begin{array}{l}0.0193 \\
0.0229 \\
0.2000\end{array}$ \\
\hline
\end{tabular}

* Diagnostic variables. 
Table B2. Balance equations of the Eco3M-CarbOx model.

\begin{tabular}{|c|c|}
\hline Variables & Balance equation \\
\hline Picophytoplankton & $\begin{array}{l}\frac{\partial \mathrm{PicoC}}{\partial t}=R_{\mathrm{PP}}^{\mathrm{PicoC}}-R_{\mathrm{resp}}^{\mathrm{PicoC}}-R_{\mathrm{exu}}^{\mathrm{PicoC}}-R_{\mathrm{Gr}} \\
\frac{\partial \mathrm{PicoN}}{\partial t}=R_{\mathrm{uptPicoN}}^{\mathrm{NH}}+R_{\mathrm{uptPicoN}}^{\mathrm{NO}_{3}}-R_{\mathrm{exu}}^{\mathrm{PicoN}}-R_{\mathrm{Gr}} \\
\frac{\partial \mathrm{PicoP}}{\partial t}=R_{\mathrm{uptPicoP}}^{\mathrm{PO}_{4}}-R_{\mathrm{exu}}^{\mathrm{PicoP}}-R_{\mathrm{Gr}} \\
\text { PicoChl }=Q_{C}^{N} \cdot\left(Q_{N, \text { min }}^{\mathrm{Chl} a}+f_{Q} \cdot\left(Q_{N, \text { max }}^{\mathrm{Chl} a}-Q_{N, \text { min }}^{\mathrm{Chl} a}\right)\right) \cdot \text { PicoC }\end{array}$ \\
\hline Diatom & $\begin{array}{l}\frac{\partial \mathrm{DiaC}}{\partial t}=R_{\mathrm{PP}}^{\mathrm{DiaC}}-R_{\mathrm{resp}}^{\mathrm{DiaC}}-R_{\mathrm{exu}}^{\mathrm{DiaC}}-R_{\mathrm{Gr}} \\
\frac{\partial \mathrm{DiaN}}{\partial t}=R_{\mathrm{uptDiaN}}^{\mathrm{NH}_{4}}+R_{\mathrm{uptDiaN}}^{\mathrm{NO}_{3}}-R_{\mathrm{exu}}^{\mathrm{DiaN}}-R_{\mathrm{Gr}} \\
\frac{\partial \mathrm{DiaP}}{\partial t}=R_{\mathrm{uptDiaP}}^{\mathrm{PO}_{4}}-R_{\mathrm{exu}}^{\mathrm{DiaP}}-R_{\mathrm{Gr}} \\
\mathrm{DiaChl}=Q_{C}^{N} \cdot\left(Q_{N, \text { min }}^{\mathrm{Chl} a}+f_{Q} \cdot\left(Q_{N, \text { max }}^{\mathrm{Chl} a}-Q_{N, \text { min }}^{\mathrm{Chl} a}\right)\right) \cdot \mathrm{DiaC}\end{array}$ \\
\hline Bacteria & $\begin{array}{l}\frac{\partial \mathrm{BacC}}{\partial t}=R_{\mathrm{uptBac}}^{\mathrm{DPOC}}+R_{\mathrm{uptBac}}^{\mathrm{LDOC}}-R_{\mathrm{BR}}-R_{\mathrm{Gr}}^{\mathrm{BacC}} \\
\frac{\partial \mathrm{BacN}}{\partial t}=R_{\mathrm{uptBac}}^{\mathrm{DPON}}+R_{\mathrm{uptBac}}^{\mathrm{LDON}}+R_{\mathrm{uptBac}}^{\mathrm{NH}_{4}}-R_{\mathrm{miner}}^{\mathrm{NH}_{4}}-R_{\mathrm{Gr}}^{\mathrm{BacN}} \\
\frac{\partial \mathrm{BacP}}{\partial t}=R_{\mathrm{uptBac}}^{\mathrm{DPOP}}+R_{\mathrm{uptBac}}^{\mathrm{LDOP}}+R_{\mathrm{uptBac}}^{\mathrm{PO}_{4}}-R_{\text {miner }}^{\mathrm{PO}_{4}}-R_{\mathrm{Gr}}^{\mathrm{BacP}}\end{array}$ \\
\hline DPOM & $\begin{array}{l}\frac{\partial \mathrm{DPOC}}{\partial t \mathrm{pf}}=R_{\mathrm{pf}}+R_{m}-R_{\mathrm{Gr}}-R_{\mathrm{uptBac}}^{\mathrm{DPOC}} \\
\frac{\partial \mathrm{DPON}}{\partial t}=R_{\mathrm{pf}}+R_{m}-R_{\mathrm{Gr}}-R_{\mathrm{uptBac}}^{\mathrm{DPON}} \\
\frac{\partial \mathrm{DPOP}}{\partial t}=R_{\mathrm{pf}}+R_{m}-R_{\mathrm{Gr}}-R_{\mathrm{uptBac}}^{\mathrm{DPOP}}\end{array}$ \\
\hline LDOM & $\begin{array}{l}\frac{\partial \mathrm{LDOC}}{\partial t}=R_{\mathrm{exu}}^{\mathrm{PicoC}}+R_{\mathrm{exu}}^{\mathrm{DiaC}}+R_{\mathrm{exu}}^{\mathrm{LDOC}}-R_{\mathrm{uptBac}}^{\mathrm{LDOC}} \\
\frac{\partial \mathrm{LDON}}{\partial t}=R_{\mathrm{exu}}^{\mathrm{PicoN}}+R_{\mathrm{exu}}^{\mathrm{DiaN}}+R_{\mathrm{exu}}^{\mathrm{LDON}}-R_{\mathrm{uptBac}}^{\mathrm{LDON}} \\
\frac{\partial \mathrm{LDOP}}{\partial t}=R_{\mathrm{exu}}^{\mathrm{PicoP}}+R_{\mathrm{exu}}^{\mathrm{DiaP}}+R_{\mathrm{exu}}^{\mathrm{LDOP}}-R_{\mathrm{uptBac}}^{\mathrm{LDOP}}\end{array}$ \\
\hline $\mathrm{NH}_{4}$ & $\frac{\partial \mathrm{NH}_{4}}{\partial t}=R_{\mathrm{excr}}^{\mathrm{NH}_{4}}+R_{\text {miner }}^{\mathrm{NH}_{4}}-R_{\text {nit }}-\sum R_{\text {uptPhyN }}^{\mathrm{NH}_{4}}-R_{\text {uptBac }}^{\mathrm{NH}_{4}}$ \\
\hline $\mathrm{NO}_{3}$ & $\frac{\partial \mathrm{NO}_{3}}{\partial t}=R_{\text {nit }}-\sum R_{\text {uptPhyN }}^{\mathrm{NO}_{3}}$ \\
\hline $\mathrm{PO}_{4}$ & $\frac{\partial \mathrm{PO}_{4}}{\partial t}=R_{\mathrm{excr}}^{\mathrm{PO}_{4}}+R_{\text {miner }}^{\mathrm{PO}_{4}}-\sum R_{\mathrm{uptPhyP}}^{\mathrm{PO}_{4}}-R_{\mathrm{uptBac}}^{\mathrm{PO}_{4}}$ \\
\hline DO & $\begin{array}{l}\frac{\partial \mathrm{DO}}{\partial t}=R_{\mathrm{aera}}+\left(\frac{O}{C}\right) \cdot R_{\mathrm{PP}}^{\mathrm{PhyC}}+\left(\frac{O}{N}\right) \cdot R_{\mathrm{uptPhyN}}^{\mathrm{NO}_{3}}-\left(\frac{O}{C}\right) \cdot R_{\mathrm{resp}}^{\mathrm{PhyC}}-\left(\frac{O}{C}\right) \cdot R_{\mathrm{excr}}^{D I C}-\left(\frac{O}{C}\right) \cdot R_{\mathrm{BR}}- \\
\left(\frac{O}{N}\right) \cdot R_{\mathrm{nit}}\end{array}$ \\
\hline DIC & $\frac{\partial \mathrm{DIC}}{\partial t}=R_{\mathrm{aera}}+R_{\mathrm{resp}}^{\mathrm{PhyC}}+R_{\mathrm{BR}}+R_{\mathrm{excr}}^{\mathrm{DIC}}-R_{\mathrm{PP}}^{\mathrm{PhyC}}-R_{\text {precip }}+R_{\text {diss }}$ \\
\hline TA & $\frac{\partial \mathrm{TA}}{\partial t}=2 \cdot R_{\text {diss }}+\left(R_{\text {uptPhyN }}^{\mathrm{NO}_{3}}+R_{\text {uptPhyP }}^{\mathrm{PO}_{4}}-R_{\text {uptPhyN }}^{\mathrm{NH}_{4}}\right)+R_{\text {miner }}^{\mathrm{NH}_{4}}-2 \cdot R_{\text {precip }}-2 \cdot R_{\text {nit }}$ \\
\hline
\end{tabular}


Table B3. Biogeochemical processes simulated by the Eco3M-CarbOx model.

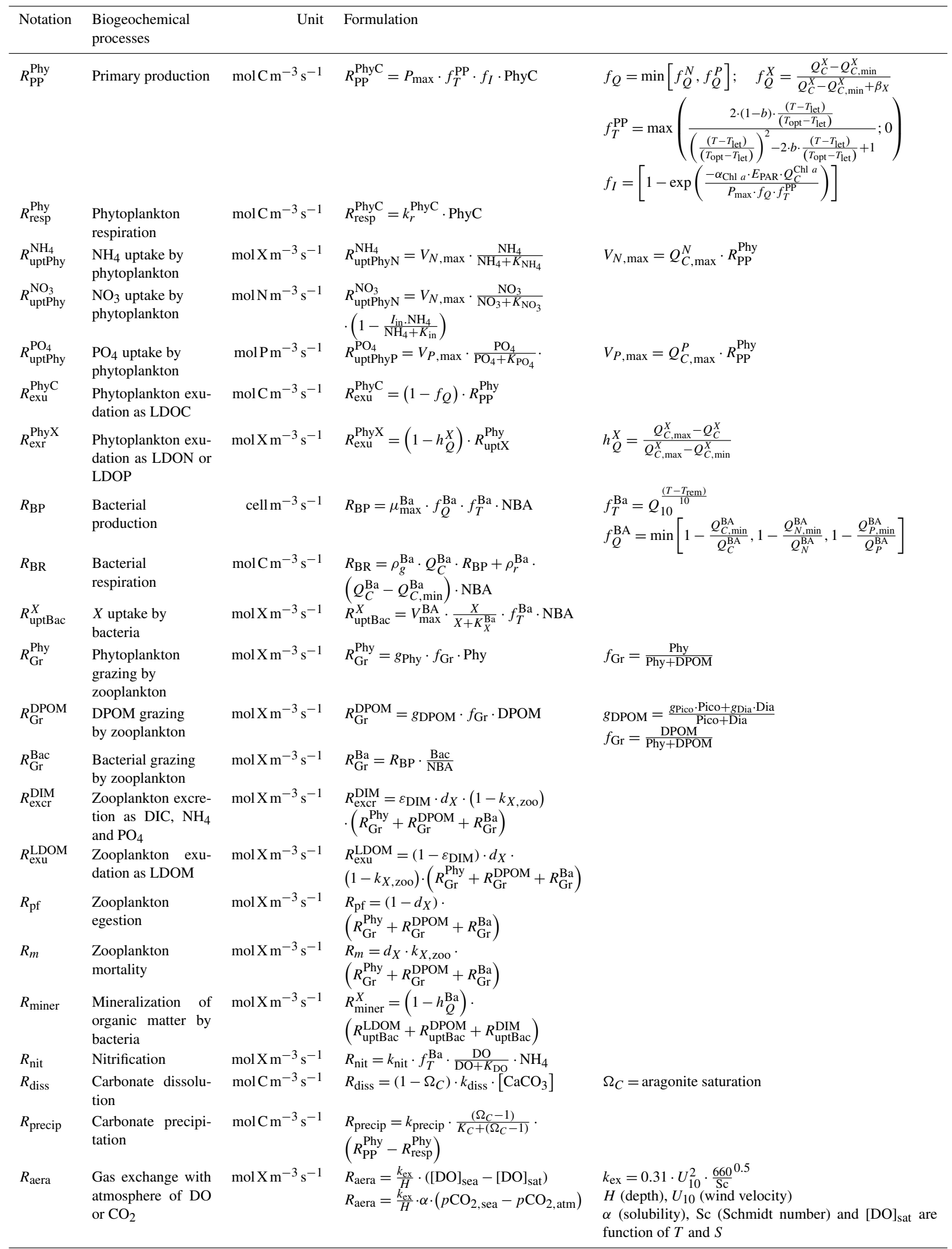


Table B4. Value of parameters.

\begin{tabular}{|c|c|c|c|c|c|}
\hline Parameters & & Pico & Dia & Unit & Reference \\
\hline$P_{m}^{C}$ & Maximal production & 1.815 & 1.057 & $d^{-1}$ & Sarthou et al. (2005) \\
\hline$m_{1}$ & $\begin{array}{l}\text { Fraction of the solar energy flux } \\
\text { photosynthetically available }\end{array}$ & 0.43 & 0.43 & - & Tett (1990) \\
\hline$m_{2}$ & Sea surface reflection & 0.95 & 0.95 & - & Tett (1990) \\
\hline$m_{3}$ & $\begin{array}{l}\text { More rapid attenuation of } \\
\text { polychromatic light near the sea surface }\end{array}$ & 1.0 & 1.0 & - & Tett (1990) \\
\hline$\alpha_{\mathrm{Chl} a}$ & $\begin{array}{l}\text { Chlorophyll-specific light absorption } \\
\text { coefficient }\end{array}$ & $8 \times 10^{-6}$ & $5 \times 10^{-6}$ & $\mathrm{~m}^{2} \operatorname{molC}(\mathrm{gChl} a \mathrm{~J})^{-1}$ & Leblanc et al. (2018) \\
\hline$T_{\mathrm{opt}}$ & Temperature optimal of growth & 16.0 & 13.0 & ${ }^{\circ} \mathrm{C}$ & - \\
\hline$T_{\text {let }}$ & Lethal temperature & 11.0 & 9.0 & ${ }^{\circ} \mathrm{C}$ & - \\
\hline$b$ & Shape factor for temperature curve & 0.5 & 0.8 & - & $\begin{array}{l}\text { Lacroix and Grégoire } \\
\text { (2002) }\end{array}$ \\
\hline$\beta_{N}$ & Coefficient in the quota function & 0.0072 & 0.002 & $\mathrm{molNmolC}^{-1}$ & Leblanc et al. (2018) \\
\hline$\beta_{P}$ & Coefficient in the quota function & 0.0002 & 0.0005 & $\operatorname{molPmolC} \mathrm{C}^{-1}$ & Leblanc et al. (2018) \\
\hline$Q_{C, \min }^{N}$ & Minimum phytoplankton $\mathrm{N}: \mathrm{C}$ ratio & 0.115 & 0.07 & $\operatorname{molNmolC}{ }^{-1}$ & Leblanc et al. (2018) \\
\hline$Q_{C, \max }^{N}$ & Maximum phytoplankton $\mathrm{N}$ : $\mathrm{C}$ ratio & 0.229 & 0.18 & $\operatorname{molNmolC}{ }^{-1}$ & Leblanc et al. (2018) \\
\hline$Q_{C, \min }^{P}$ & Minimum phytoplankton $\mathrm{P}: \mathrm{C}$ ratio & 0.0015 & 0.006 & $\operatorname{molP} \mathrm{molC}^{-1}$ & $\begin{array}{l}\text { Auger et al. (2011); } \\
\text { Campbell et al. (2013) }\end{array}$ \\
\hline$Q_{C, \max }^{P}$ & Maximum phytoplankton $\mathrm{P}: \mathrm{C}$ ratio & 0.0068 & 0.016 & $\operatorname{molPmolC}{ }^{-1}$ & $\begin{array}{l}\text { Auger et al. (2011); } \\
\text { Campbell et al. (2013) }\end{array}$ \\
\hline$Q_{N, \min }^{\mathrm{Chl} a}$ & Minimum phytoplankton $\mathrm{Chl}: \mathrm{N}$ ratio & 1.0 & 1.0 & $\mathrm{gChl} \mathrm{molN}^{-1}$ & Leblanc et al. $(2018)^{*}$ \\
\hline$Q_{N, \max }^{\mathrm{Chl} a}$ & Maximum phytoplankton $\mathrm{Chl}: \mathrm{N}$ ratio & 2.2 & 2.7 & $\mathrm{gChl} \mathrm{molN}^{-1}$ & Leblanc et al. (2018) \\
\hline$k_{r}^{\mathrm{PhyC}}$ & Phytoplankton respiration rate & 0.099 & 0.099 & $\mathrm{~d}^{-1}$ & Faure et al. (2010) \\
\hline$K_{\mathrm{NO}_{3}}$ & Half-saturation constant for $\mathrm{NO}_{3}$ & 0.73 & 1.0 & $\mathrm{mmolNm}^{-3}$ & Leblanc et al. (2018) \\
\hline$K_{\mathrm{NH}_{4}}$ & Half-saturation constant for $\mathrm{NH}_{4}$ & 0.07 & 0.015 & $\mathrm{mmolNm}^{-3}$ & Leblanc et al. (2018) \\
\hline$K_{\mathrm{PO}_{4}}$ & Half-saturation constant for $\mathrm{PO}_{4}$ & 0.008 & 0.01 & $\mathrm{mmolPm}^{-3}$ & Leblanc et al. (2018)* \\
\hline$I_{\text {in }}$ & Factor of inhibition & 0.82 & 0.82 & - & Harrison et al. (1996) \\
\hline$K_{\text {in }}$ & $\begin{array}{l}\text { Amount of } \mathrm{NH}_{4} \text { from which } \\
\text { assimilation by } \mathrm{NO}_{3} \text { is reduced. }\end{array}$ & 0.578 & 0.578 & $\mathrm{mmolNm}^{-3}$ & Harrison et al. (1996) \\
\hline$g$ & Grazing rate & 1.452 & 0.846 & $d^{-1}$ & $\begin{array}{l}\text { Gutiérrez-Rodríguez } \\
\text { et al. (2011) }\end{array}$ \\
\hline
\end{tabular}

* Calibrated from parameter used in the cited article. 
Table B4. Continued.

\begin{tabular}{|c|c|c|c|c|}
\hline Parameters & & Value & Unit & Reference \\
\hline NBA & Number of bacteria & 0.20 & $10^{12}$ cell m$^{-3}$ & Moran (2015) \\
\hline$\mu_{\max }^{\mathrm{Ba}}$ & Bacterial production rate & 8.36 & $\mathrm{~d}^{-1}$ & Fraysse et al. (2013) \\
\hline$Q_{C, \min }^{\mathrm{BA}}$ & Minimum bacteria $\mathrm{C}$ : cell ratio & 0.49 & $\operatorname{mmolC}\left(10^{12} \text { cell }\right)^{-1}$ & Fukuda et al. (1998) \\
\hline$Q_{N, \min }^{\mathrm{BA}}$ & Minimum bacteria $\mathrm{N}$ : cell ratio & 0.09 & $\operatorname{mmolN}\left(10^{12} \text { cell }\right)^{-1}$ & Fukuda et al. (1998) \\
\hline$Q_{N, \max }^{\mathrm{BA}}$ & Maximum bacteria $\mathrm{N}$ : cell ratio & 0.23 & $\operatorname{mmolN}\left(10^{12} \text { cell }\right)^{-1}$ & Fukuda et al. (1998) \\
\hline$Q_{P, \min }^{\mathrm{BA}}$ & Minimum bacteria $\mathrm{P}$ : cell ratio & 0.005 & $\operatorname{mmolP}\left(10^{12} \text { cell }\right)^{-1}$ & Fraysse et al. (2013) \\
\hline$Q_{P, \max }^{\mathrm{BA}}$ & Maximum bacteria $\mathrm{P}$ : cell ratio & 0.02 & $\operatorname{mmolP}\left(10^{12} \text { cell }\right)^{-1}$ & Fraysse et al. (2013) \\
\hline$\rho_{g}^{\mathrm{Ba}}$ & Factor of carbon respired by bacteria & 0.60 & - & Thingstad (1987) \\
\hline$\rho_{r}^{\mathrm{Ba}}$ & Respiration rate of bacteria & 0.01 & $\mathrm{~d}^{-1}$ & Thingstad (1987) \\
\hline$V_{\mathrm{DPOC}, \max }^{\mathrm{BA}}$ & Maximum DPOC uptake by bacteria & 0.029 & $\operatorname{mmolC}\left(10^{12} \text { cell }\right)^{-1} \mathrm{~d}^{-1}$ & Campbell et al. (2013) \\
\hline$V_{\mathrm{LDOC}, \max }^{\mathrm{BA}}$ & Maximum LDOC uptake by bacteria & 16.33 & $\operatorname{mmolC}\left(10^{12} \text { cell }\right)^{-1} \mathrm{~d}^{-1}$ & Campbell et al. (2013) \\
\hline$V_{\mathrm{DPON}, \max }^{\mathrm{BA}}$ & Maximum DPON uptake by bacteria & 0.05 & $\operatorname{mmolN}\left(10^{12} \text { cell }\right)^{-1} \mathrm{~d}^{-1}$ & Faure et al. (2010) \\
\hline$V_{\mathrm{LDON}, \max }^{\mathrm{BA}}$ & Maximum LDON uptake by bacteria & 0.32 & $\operatorname{mmolN}\left(10^{12} \text { cell }\right)^{-1} \mathrm{~d}^{-1}$ & Faure et al. (2010) \\
\hline$V_{\mathrm{NH}_{4}, \max }^{\mathrm{BA}}$ & Maximum $\mathrm{NH}_{4}$ uptake by bacteria & 0.32 & $\operatorname{mmolN}\left(10^{12} \text { cell }\right)^{-1} \mathrm{~d}^{-1}$ & Faure et al. (2010) \\
\hline$V_{\mathrm{DPOP}, \max }^{\mathrm{BA}}$ & Maximum DPOP uptake by bacteria & 0.01 & $\operatorname{mmolP}\left(10^{12} \text { cell }\right)^{-1} \mathrm{~d}^{-1}$ & Thingstad (1987) \\
\hline$V_{\mathrm{LDOP}, \max }^{\mathrm{BA}}$ & Maximum LDOP uptake by bacteria & 0.48 & $\operatorname{mmolP}\left(10^{12} \text { cell }\right)^{-1} \mathrm{~d}^{-1}$ & Thingstad (1987) \\
\hline$V_{\mathrm{PO}_{4}, \max }^{\mathrm{BA}}$ & Maximum $\mathrm{PO}_{4}$ uptake by bacteria & 0.48 & $\operatorname{mmolP}\left(10^{12} \text { cell }\right)^{-1} \mathrm{~d}^{-1}$ & Thingstad (1987) \\
\hline$K_{\mathrm{DPOC}}^{\mathrm{BA}}$ & Half-saturation constant for DPOC & 10.0 & $\mathrm{mmolCm}^{-3}$ & Faure et al. (2010) \\
\hline$K_{\mathrm{LDOC}}^{\mathrm{BA}}$ & Half-saturation constant for LDOC & 25.0 & $\mathrm{mmolCm}^{-3}$ & - \\
\hline$K_{\mathrm{DPON}}^{\mathrm{BA}}$ & Half-saturation constant for DPON & 0.50 & $\mathrm{mmolNm}^{-3}$ & - \\
\hline$K_{\mathrm{LDON}}^{\mathrm{BA}}$ & Half-saturation constant for LDON & 0.50 & $\mathrm{mmolNm}^{-3}$ & - \\
\hline$K_{\mathrm{NH}_{4}}^{\mathrm{BA}_{4}}$ & Half-saturation constant for $\mathrm{NH}_{4}$ & 0.15 & $\mathrm{mmolNm}^{-3}$ & Leblanc et al. (2018) \\
\hline$K_{\mathrm{DPOP}}^{\mathrm{BA}}$ & Half-saturation constant for DPOP & 0.08 & $\mathrm{mmolPm}^{-3}$ & - \\
\hline$K_{\mathrm{LDOP}}^{\mathrm{BA}}$ & Half-saturation constant for LDOP & 0.08 & $\mathrm{mmolPm}^{-3}$ & Leblanc et al. (2018) \\
\hline$K_{\mathrm{PO}_{4}}^{\mathrm{BA}}$ & Half-saturation constant for $\mathrm{PO}_{4}$ & 0.02 & $\mathrm{mmolPm}^{-3}$ & Campbell et al. (2013) \\
\hline$\varepsilon_{\text {DIC }}$ & fraction excretion of DIC & 0.31 & - & Faure et al. (2010) \\
\hline$\varepsilon_{\mathrm{NH}_{4}}$ & fraction excretion of $\mathrm{NH}_{4}$ & 0.50 & - & Faure et al. (2010) \\
\hline$\varepsilon_{\mathrm{PO}_{4}}$ & Fraction excretion of $\mathrm{PO}_{4}$ & 0.50 & - & Fraysse et al. (2013) \\
\hline$d_{\mathrm{C}}$ & Fraction of $\mathrm{C}$ assimilated & 0.92 & - & Gerber and Gerber (1979) \\
\hline$d_{\mathrm{N}}$ & Fraction of $\mathrm{N}$ assimilated & 0.95 & - & Faure et al. (2010) \\
\hline$d_{\mathrm{P}}$ & Fraction of $\mathrm{P}$ assimilated & 0.95 & - & Fraysse et al. (2013) \\
\hline$k_{\mathrm{C}, \text { zoo }}$ & Net $\mathrm{C}$ growth efficiency & 0.40 & - & Gerber and Gerber (1979) \\
\hline$k_{\mathrm{N}, \mathrm{ZOo}}$ & Net $\mathrm{N}$ growth efficiency & 0.44 & - & Le Borgne and Rodier (1997) \\
\hline$k_{\mathrm{P}, \mathrm{zoo}}$ & Net $P$ growth efficiency & 0.37 & - & Le Borgne (1982) \\
\hline$Q_{10}$ & Temperature coefficient & 2.0 & - & - \\
\hline$T_{\text {rem }}$ & Reference temperature for mineralization & 20.0 & ${ }^{\circ} \mathrm{C}$ & - \\
\hline$k_{\text {nit }}$ & Nitrification rate & 0.05 & $d^{-1}$ & Lacroix and Grégoire (2002) \\
\hline$T_{\text {nit }}$ & Reference temperature for nitrification & 10.0 & ${ }^{\circ} \mathrm{C}$ & - \\
\hline$K_{\mathrm{DO}}$ & Half-saturation constant DO & 30.0 & $\mathrm{mmolO}_{2} \mathrm{~m}^{-3}$ & Tett (1990) \\
\hline$k_{\text {diss }}$ & Dissolution rate & 10.9 & $\mathrm{~d}^{-1}$ & Gehlen et al. (2007) \\
\hline$k_{\text {precip }}$ & Fraction of PIC to LPOC & 0.02 & - & Marty et al. (2002) \\
\hline$K_{C}$ & Half-saturation constant of $\mathrm{CaCO}_{3}$ precipitation & 0.40 & $\left(\mu \mathrm{mol} \mathrm{kg}{ }^{-1}\right)^{2}$ & \\
\hline$\left(\frac{\mathrm{O}}{\mathrm{C}}\right)$ & Ratio O : C & 1.0 & - & - \\
\hline$\left(\begin{array}{l}\mathrm{O} \\
\mathrm{N}\end{array}\right)$ & Ratio $\mathrm{O}: \mathrm{N}$ & 2.0 & - & - \\
\hline
\end{tabular}




\section{Appendix C: Short user manual}

After uploading the whole archive on the

Zenodo site (Lajaunie-Salla et al., 2020; https://doi.org/10.5281/zenodo.3757677), the exact version of the Eco3M-CarbOx code used in this study can be run as follows:

make !two executable files will be created: eco3M_ini.exe and eco3M.exe

Please note the following:

- The file config.ini allows the following to be defined: the time, time step, and save time of simulation variables biogeochemical process.

- Results files are stocked in "SORTIES" directory.

- Boundary conditions and forcings data are stocked in "DATA" directory.

- All subroutines of biogeochemical processes are stocked in "F_PROCESS" directory.

For further information, please contact Frédéric Diaz (frederic.diaz@univ-amu.fr) or Christel Pinazo (christel.pinazo@univ-amu.fr). 
Code availability. Eco3M is freely available under the CeCILL license agreement (a French equivalent to the L-GPL license; http://cecill.info/licences/Licence_CeCILL_V1.1-US.html (last access: 10 February 2020). The Eco3M-CarbOx model is written in Fortran-90/95 and the plotting code is written in MATLAB ${ }^{\circledR}$. The exact version of the model used to produce the results presented in this paper is archived on Zenodo (Lajaunie-Salla et al., 2020; https://doi.org/10.5281/zenodo.3757677)). A short user manual is given in Appendix $\mathrm{C}$ of this study.

Author contributions. KLS conceptualized this study, made code developments on the carbonate module, designed the numerical experiments, performed the final analysis to the model results (validation, statistics), developed MATLAB ${ }^{\circledR}$ software to visualize the results of model and statistics tests, wrote and edited the initial draft, revised the manuscript, and answered reviewers. FD participated in the conceptualization of the present study, supervised this research, wrote some parts of the initial draft, helped to answer reviewer comments, revised the draft after the second review, and edited the final version. CWR participated in the data acquisition of the seawater $p \mathrm{CO}_{2}$ and corresponding measurements at the laboratory and reviewed and helped with the initial draft. TW participated in the data acquisition of the seawater $p \mathrm{CO}_{2}$ and corresponding measurements at the laboratory, helped to answer reviews, and helped with the final editing. DL acquired funding, conducted the project administration, and participated in the data acquisition of the seawater $p \mathrm{CO}_{2} . \mathrm{CY}$ helped to maintain computing resources and gave expertise on the Eco3M-CarbOx code and software developments and compiling. IX-R acquired funding, conducted the project administration, and provided data on the atmospheric $p \mathrm{CO}_{2}$ at $\mathrm{OHP}$. BN participated in the acquisition of $p \mathrm{CO}_{2}$ data at $\mathrm{OHP}$ and reviewed and edited the first submitted draft. AA provided temporal data on the atmospheric $p \mathrm{CO}_{2}$ at $\mathrm{CAV}$. CP participated in the conceptualization of the present study, provided the initial Eco3M code (without the carbonate module), supervised this research, reviewed the initial draft, and helped to answer reviewer comments.

Competing interests. The authors declare that they have no conflict of interest.

Acknowledgements. We thank the National Service d'Observation en MILieu Littoral (SOMLIT) for its permission to use SOLEMIO data. We wish to thank the crew members of the RV Antedon II, operated by the DT-INSU, for making these samplings possible. We wish to acknowledge the team of the SAM platform (Service Atmosphère Mer) of the MIO institute for their help with the field work. For the collection and analyses of the seawater sample, we thank Michel Lafont and Véronique Lagadec of the PACEM (Plateforme Analytique de Chimie des Environnenments Marins) platform of the MIO institute and also the SNAPO-CO2 at LOCEAN, Paris. The SNAPO-CO2 service at LOCEAN is supported by CNRS-INSU and OSU Ecce-Terra.

We acknowledge the staff of the "Cluster de calcul intensif HPC" platform of the OSU Institut PYTHEAS (Aix-Marseille Université, INSU-CNRS) for providing the computing facilities. We gratefully acknowledge Julien Lecubin from the Service Informatique de OSU
Institut PYTHEAS (SIP) for their technical assistance. Moreover, we thank Camille Mazoyer and Claire Seceh for their contribution to the Eco3M-CarbOx model development.

Financial support. This study is part of the AMC project (AixMarseille Carbon Pilot Study, 2016-2019), funded and performed in the framework of the Labex OT-MED (ANR-11-LABEX0061, part of the "Investissement d'Avenir" program through the A*MIDEX project ANR-11-IDEX-0001-02), which is funded by the French National Research Agency (ANR). The project leading to this publication has received funding from the European FEDER Fund under project 1166-39417.

Review statement. This paper was edited by Sandra Arndt and reviewed by Guy Munhoven and Sebastiaan van de Velde.

\section{References}

Abril, G., Commarieu, M. V., Sottolichio, A., Bretel, P., and Guérin, F.: Turbidity limits gas exchange in a large macrotidal estuary, Estuar. Coast. Shelf S., 83, 342-348, https://doi.org/10.1016/j.ecss.2009.03.006, 2009.

Allen, M. R., Frame, D. J., Huntingford, C., Jones, C., Lowe, J. A., Meinshausen, M., and Meinshausen, N.: Warming caused by cumulative carbon emissions towards the trillionth tonne, Nature, 458, 1163-1166, https://doi.org/10.1038/nature08019, 2009.

Andersson, A. J. and Mackenzie, F. T.: Shallow-water oceans: a source or sink of atmospheric $\mathrm{CO}_{2}$ ?, Front. Ecol. Environ., 2, 348-353, https://doi.org/10.1890/15409295(2004)002[0348:SOASOS]2.0.CO;2, 2004.

Andersson, A. J. and Mackenzie, F. T.: Revisiting four scientific debates in ocean acidification research, Biogeosciences, 9, 893905, https://doi.org/10.5194/bg-9-893-2012, 2012.

Auger, P. A., Diaz, F., Ulses, C., Estournel, C., Neveux, J., Joux, F., Pujo-Pay, M., and Naudin, J. J.: Functioning of the planktonic ecosystem on the Gulf of Lions shelf (NW Mediterranean) during spring and its impact on the carbon deposition: a field data and 3D modelling combined approach, Biogeosciences, 8, 3231-3261, https://doi.org/10.5194/bg-8-3231-2011, 2011.

Baklouti, M., Faure, V., Pawlowski, L., and Sciandra, A.: Investigation and sensitivity analysis of a mechanistic phytoplankton model implemented in a new modular numerical tool (Eco3M) dedicated to biogeochemical modelling, Prog. Oceanogr., 71, 34-58, https://doi.org/10.1016/j.pocean.2006.05.003, 2006.

Borges, A. V. and Abril, G.: Carbon dioxide and methane dynamics in estuaries, in :Treatise on Estuarine and Coastal Science, edited by: Wolanski, E. and McLusky, D., Academic Press, Waltham, 119-161, 2011.

Cai, W.-J.: Estuarine and coastal ocean carbon paradox: $\mathrm{CO}_{2}$ sinks or sites of terrestrial carbon incineration?, Annu. Rev. Mar. Sci., 3, 123-145, https://doi.org/10.1146/annurev-marine120709-142723, 2011.

Cai, W.-J., Hu, X., Huang, W.-J., Murrell, M. C., Lehrter, J. C., Lohrenz, S. E., Chou, W.-C., Zhai, W., Hollibaugh, J. T., Wang, Y., Zhao, P., Guo, X., Gundersen, K., Dai, M., and Gong, G.-C.: Acidification of subsurface coastal wa- 
ters enhanced by eutrophication, Nat. Geosci., 4, 766-770, https://doi.org/10.1038/ngeo1297, 2011.

Campbell, R., Diaz, F., Hu, Z., Doglioli, A., Petrenko, A., and Dekeyser, I.: Nutrients and plankton spatial distributions induced by a coastal eddy in the Gulf of Lion. Insights from a numerical model, Prog. Oceanogr., 109, 47-69, https://doi.org/10.1016/j.pocean.2012.09.005, 2013.

Chen, C.-T. A. and Borges, A. V: Reconciling opposing views on carbon cycling in the coastal ocean: Continental shelves as sinks and near-shore ecosystems as sources of atmospheric $\mathrm{CO}_{2}$, Deep-Sea Res. Pt. II, 56, 578-590, https://doi.org/10.1016/j.dsr2.2009.01.001, 2009.

Chen, C.-T. A., Huang, T.-H., Chen, Y.-C., Bai, Y., He, X., and Kang, Y.: Air-sea exchanges of $\mathrm{CO}_{2}$ in the world's coastal seas, Biogeosciences, 10, 6509-6544, https://doi.org/10.5194/bg-106509-2013, 2013.

Cloern, J. E.: Our evolving conceptual model of the coastal eutrophication problem, Mar. Ecol. Prog. Ser., 210, 223-253, https://doi.org/10.3354/meps210223, 2001.

Cloern, J. E., Foster, S. Q., and Kleckner, A. E.: Phytoplankton primary production in the world's estuarine-coastal ecosystems, Biogeosciences, 11, 2477-2501, https://doi.org/10.5194/bg-112477-2014, 2014.

Cocco, V., Joos, F., Steinacher, M., Frölicher, T. L., Bopp, L., Dunne, J., Gehlen, M., Heinze, C., Orr, J., Oschlies, A., Schneider, B., Segschneider, J., and Tjiputra, J.: Oxygen and indicators of stress for marine life in multi-model global warming projections, Biogeosciences, 10, 1849-1868, https://doi.org/10.5194/bg-10-1849-2013, 2013.

Copin-Montégut, C., Bégovic, M., and Merlivat, L.: Variability of the partial pressure of $\mathrm{CO}_{2}$ on diel to annual time scales in the Northwestern Mediterranean Sea, Mar. Chem., 85, 169-189, https://doi.org/10.1016/j.marchem.2003.10.005, 2004.

De Carlo, E. H., Mousseau, L., Passafiume, O., Drupp, P. S., and Gattuso, J.-P.: Carbonate Chemistry and Air-Sea $\mathrm{CO}_{2}$ Flux in a NW Mediterranean Bay Over a Four-Year Period: 2007-2011, Aquat. Geochem., 19, 399-442, https://doi.org/10.1007/s10498013-9217-4, 2013.

Dickson, A. G.: Standard potential of the reaction: $\mathrm{AgCl}(\mathrm{s})+12 \mathrm{H}_{2}(\mathrm{~g})=\mathrm{Ag}(\mathrm{s})+\mathrm{HCl}(\mathrm{aq})$, and and the standard acidity constant of the ion $\mathrm{HSO}_{4}^{-}$in synthetic sea water from 273.15 to $318.15 \mathrm{~K}$, J. Chem. Thermodyn., 22, 113-127, https://doi.org/10.1016/0021-9614(90)90074-Z, 1990a.

Dickson, A. G.: Thermodynamics of the dissociation of boric acid in synthetic seawater from 273.15 to $318.15 \mathrm{~K}$, Deep-Sea Res., 37, 755-766, https://doi.org/10.1016/0198-0149(90)90004-F, 1990b.

Dickson, A. G. and Riley, J. P.: The estimation of acid dissociation constants in sea-water media from potentiometric titrations with strong base. II. The dissociation of phosphoric acid, Mar. Chem., 7, 101-109, https://doi.org/10.1016/03044203(79)90002-1, 1979.

Doney, S. C., Tilbrook, B., Roy, S., Metzl, N., Le Quéré, C., Hood, M., Feely, R. A., and Bakker, D.: Surface-ocean $\mathrm{CO}_{2}$ variability and vulnerability, Deep-Sea Res. Pt. II, 56, 504-511, https://doi.org/10.1016/j.dsr2.2008.12.016, 2009.

Esbaugh, A. J., Heuer, R., and Grosell, M.: Impacts of ocean acidification on respiratory gas exchange and acid-base balance in a marine teleost, Opsanus beta, J. Comp. Physiol. B, 182, 921-934, https://doi.org/10.1007/s00360-012-0668-5, 2012.

Faure, V., Pinazo, C., Torréton, J.-P., and Jacquet, S.: Modelling the spatial and temporal variability of the SW lagoon of New Caledonia I: A new biogeochemical model based on microbial loop recycling, Mar. Pollut. Bull., 61, 465-479, https://doi.org/10.1016/j.marpolbul.2010.06.041, 2010.

Fraysse, M., Pinazo, C., Faure, V., Fuchs, R., Lazzari, P., Raimbault, P., and Pairaud, I.: Development of a 3D coupled physical-biogeochemical model for the Marseille coastal area (NW Mediterranean Sea): What complexity is required in the Coastal Zone?, PLoS One, 8, 1-18, https://doi.org/10.1371/journal.pone.0080012, 2013.

Fraysse, M., Pairaud, I., Ross, O. N., Faure, V., and Pinazo, C.: Intrusion of Rhône River diluted water into the Bay of Marseille: Generation processes and impacts on ecosystem functioning, J. Geophys. Res.-Oceans, 119, 6535-6556, https://doi.org/10.1002/2014JC010022, 2014.

Fukuda, R., Ogawa, H., Nagata, T., and Koike, I.: Direct Determination of Carbon and Nitrogen Contents of Natural Bacterial Assemblages in Marine Environments, Appl. Environ. Microb., 64, 3352-3358, https://doi.org/10.1128/AEM.64.9.3352-3358.1998, 1998.

Gatti, J., Petrenko, A., Devenon, J.-L., Leredde, Y., and Ulses, C.: The Rhône river dilution zone present in the northeastern shelf of the Gulf of Lion in December 2003, Cont. Shelf Res., 26, 17941805, https://doi.org/10.1016/j.csr.2006.05.012, 2006.

Gattuso, J.-P., Frankignoulle, M., and Wollast, R.: Carbon and carbonate metabolism in coastal aquatic ecosystems, Annu. Rev. Ecol. Syst., 29, 405-34, https://doi.org/10.1146/annurev.ecolsys.29.1.405, 1998.

Gattuso, J.-P., Magnan, A., Bille, R., Cheung, W. W. L., Howes, E. L., Joos, F., Allemand, D., Bopp, L., Cooley, S. R., Eakin, C. M., Hoegh-Guldberg, O., Kelly, R. P., Portner, H.O., Rogers, A. D., Baxter, J. M., Laffoley, D., Osborn, D., Rankovic, A., Rochette, J., Sumaila, U. R., Treyer, S., and Turley, C.: Contrasting futures for ocean and society from different anthropogenic $\mathrm{CO}_{2}$ emissions scenarios, Science, 349, https://doi.org/10.1126/science.aac4722, 2015.

Gehlen, M., Gangstø, R., Schneider, B., Bopp, L., Aumont, O., and Ethe, C.: The fate of pelagic $\mathrm{CaCO}_{3}$ production in a high $\mathrm{CO}_{2}$ ocean: a model study, Biogeosciences, 4, 505-519, https://doi.org/10.5194/bg-4-505-2007, 2007.

Gemayel, E., Hassoun, A. E. R., Benallal, M. A., Goyet, C., Rivaro, P., Abboud-Abi Saab, M., Krasakopoulou, E., Touratier, F., and Ziveri, P.: Climatological variations of total alkalinity and total dissolved inorganic carbon in the Mediterranean Sea surface waters, Earth Syst. Dynam., 6, 789-800, https://doi.org/10.5194/esd-6-789-2015, 2015.

Gerber, R. P. and Gerber, M. B.: Ingestion of natural particulate organic matter and subsequent assimilation, respiration and growth by tropical lagoon zooplankton, Mar. Biol., 52, 33-43, https://doi.org/10.1007/BF00386855, 1979.

Gouze, E., Raimbault, P., Garcia, N., and Picon, P.: Nutrient dynamics and primary production in the eutrophic Berre Lagoon (Mediterranean, France), Transitional Waters Bull., 2, 17-40, https://doi.org/10.1285/i18252273v2n2p17, 2008.

Gruber, N., Clement, D., Carter, B. R., Feely, R. A., van Heuven, S., Hoppema, M., Ishii, M., Key, R. M., Kozyr, A., Lauvset, S. K., 
Lo Monaco, C., Mathis, J. T., Murata, A., Olsen, A., Perez, F. F., Sabine, C. L., Tanhua, T., and Wanninkhof, R. H.: The oceanic sink for anthropogenic $\mathrm{CO}_{2}$ from 1994 to 2007, Science, 363, 1193-1199, https://doi.org/10.1126/science.aau5153, 2019.

Gutiérrez-Rodríguez, A., Latasa, M., Scharek, R., Massana, R., Vila, G., and Gasol, J. M.: Growth and grazing rate dynamics of major phytoplankton groups in an oligotrophic coastal site, Estuar. Coast. Shelf S., 95, 77-87, https://doi.org/10.1016/j.ecss.2011.08.008, 2011.

Harrison, W. G., Harris, L. R., and Irwin, B. D.: The kinetics of nitrogen utilization in the oceanic mixed layer: Nitrate and ammonium interactions at nanomolar concentrations, Limnol. Oceanogr., 41, 16-32, https://doi.org/10.4319/lo.1996.41.1.0016, 1996.

Herrmann, M., Somot, S., Calmanti, S., Dubois, C., and Sevault, F.: Representation of spatial and temporal variability of daily wind speed and of intense wind events over the Mediterranean Sea using dynamical downscaling: impact of the regional climate model configuration, Nat. Hazards Earth Syst. Sci., 11, 19832001, https://doi.org/10.5194/nhess-11-1983-2011, 2011.

Hoegh-Guldberg, O., Jacob, D., Taylor, M., Bindi, M., Brown, S., Camilloni, I., Diedhiou, A., Djalante, R., Ebi, K., Engelbrecht, F., Guiot, J., Hijioka, Y., Mehrotra, S., Payne, A., Seneviratne, S. I., Thomas, A., Warren, R., and Zhou, G.: Impacts of $1.5^{\circ} \mathrm{C}$ Global Warming on Natural and Human Systems, in Global warming of $1.5^{\circ} \mathrm{C}$. An IPCC Special Report on the impacts of global warming of $1.5^{\circ} \mathrm{C}$ above pre-industrial levels and related global greenhouse gas emission pathways, in the context of strengthening the global response to the threat of climate change, edited by: Masson-Delmotte, V., Zhai, P., Pörtner, H. O., Roberts, D., Skea, J., Shukla, P. R., Pirani, A., Moufouma-Okia, W., Péan, C., Pidcock, R., Connors, S., Matthews, J. B. R., Chen, Y., Zhou, X., Gomis, M. I., Lonnoy, E., Maycock, T., Tignor, M., and Waterfield, T., World Meteorological Organization Technical Document, 2018.

Kapsenberg, L., Alliouane, S., Gazeau, F., Mousseau, L., and Gattuso, J.-P.: Coastal ocean acidification and increasing total alkalinity in the northwestern Mediterranean Sea, Ocean Sci., 13, 411-426, https://doi.org/10.5194/os-13-411-2017, 2017.

Lacroix, G. and Grégoire, M.: Revisited ecosystem model (MODECOGeL) of the Ligurian Sea: seasonal and interannual variability due to atmospheric forcing, J. Marine Syst., 37, 229-258, https://doi.org/10.1016/S0924-7963(02)00190-2, 2002.

Lajaunie-Salla, K., Diaz, F., and Pinazo, C.: configuration files and code for Eco3M-CarbOx v1.1, Zenodo, https://doi.org/10.5281/zenodo.3757677, 2020.

Le Borgne, R.: Zooplankton production in the eastern tropical Atlantic Ocean: Net growth efficiency and P : B in terms of carbon, nitrogen, and phosphorus, Limnol. Oceanogr., 27, 681-698, https://doi.org/10.4319/lo.1982.27.4.0681, 1982.

Le Borgne, R. and Rodier, M.: Net zooplankton and the biological pump: a comparison between the oligotrophic and mesotrophic equatorial Pacific, Deep-Sea Res. Pt. II, 44, 20032023, https://doi.org/10.1016/S0967-0645(97)00034-9, 1997.

Le Quéré, C., Andrew, R. M., Friedlingstein, P., Sitch, S., Hauck, J., Pongratz, J., Pickers, P. A., Korsbakken, J. I., Peters, G. P., Canadell, J. G., Arneth, A., Arora, V. K., Barbero, L., Bastos, A., Bopp, L., Chevallier, F., Chini, L. P., Ciais, P., Doney, S. C., Gkritzalis, T., Goll, D. S., Harris, I., Haverd, V., Hoffman, F. M.,
Hoppema, M., Houghton, R. A., Hurtt, G., Ilyina, T., Jain, A. K., Johannessen, T., Jones, C. D., Kato, E., Keeling, R. F., Goldewijk, K. K., Landschützer, P., Lefèvre, N., Lienert, S., Liu, Z., Lombardozzi, D., Metzl, N., Munro, D. R., Nabel, J. E. M. S., Nakaoka, S., Neill, C., Olsen, A., Ono, T., Patra, P., Peregon, A., Peters, W., Peylin, P., Pfeil, B., Pierrot, D., Poulter, B., Rehder, G., Resplandy, L., Robertson, E., Rocher, M., Rödenbeck, C., Schuster, U., Schwinger, J., Séférian, R., Skjelvan, I., Steinhoff, T., Sutton, A., Tans, P. P., Tian, H., Tilbrook, B., Tubiello, F. N., van der Laan-Luijkx, I. T., van der Werf, G. R., Viovy, N., Walker, A. P., Wiltshire, A. J., Wright, R., Zaehle, S., and Zheng, B.: Global Carbon Budget 2018, Earth Syst. Sci. Data, 10, 21412194, https://doi.org/10.5194/essd-10-2141-2018, 2018.

Leblanc, K., Quéguiner, B., Diaz, F., Cornet, V., Michel-Rodriguez, M., Durrieu de Madron, X., Bowler, C., Malviya, S., Thyssen, M., Grégori, G., Rembauville, M., Grosso, O., Poulain, J., de Vargas, C., Pujo-Pay, M., and Conan, P.: Nanoplanktonic diatoms are globally overlooked but play a role in spring blooms and carbon export, Nat. Commun., 9, 953, https://doi.org/10.1038/s41467-018-03376-9, 2018.

Lueker, T. J., Dickson, A. G., and Keeling, C. D.: Ocean $\mathrm{pCO}_{2}$ calculated from dissolved inorganic carbon, alkalinity, and equations for $\mathrm{K} 1$ and $\mathrm{K} 2$ : Validation based on laboratory measurements of $\mathrm{CO}_{2}$ in gas and seawater at equilibrium, Mar. Chem., 70, 105-119, https://doi.org/10.1016/S0304-4203(00)00022-0, 2000.

Margalef, R.: Life-forms of phytoplankton as survival alternatives in an unstable environment, edited by: Gauthier-Villars, Oceanol. Acta, 1, 493-509, available at: https://archimer.ifremer.fr/doc/ 00123/23403/ (last access: December 2019), 1978.

Marty, J.-C., Chiavérini, J., Pizay, M.-D., and Avril, B.: Seasonal and interannual dynamics of nutrients and phytoplankton pigments in the western Mediterranean Sea at the DYFAMED timeseries station (1991-1999), Deep-Sea Res. Pt. II, 49, 1965-1985, https://doi.org/10.1016/S0967-0645(02)00022-X, 2002.

Matthews, H. D., Gillett, N. P., Stott, P. A., and Zickfeld, K.: The proportionality of global warming to cumulative carbon emissions, Nature, 459, 829-32, https://doi.org/10.1038/nature08047, 2009.

Mella-Flores, D., Mazard, S., Humily, F., Partensky, F., Mahé, F., Bariat, L., Courties, C., Marie, D., Ras, J., Mauriac, R., Jeanthon, C., Mahdi Bendif, E., Ostrowski, M., Scanlan, D. J., and Garczarek, L.: Is the distribution of Prochlorococcus and Synechococcus ecotypes in the Mediterranean Sea affected by global warming?, Biogeosciences, 8, 2785-2804, https://doi.org/10.5194/bg-8-2785-2011, 2011.

Middelburg, J. J.: Marine carbon biogeochemistry. A primer for earth system scientists, Springer Briefs in Earth System Sciences, Springer Nature Switzerland AG, Cham, Switzerland, 2019.

Millero, F. J.: Thermodynamics Seawater - 1. The PVT Properties, Ocean Science and Engineering, 7, 403-460 1982.

Millero, F. J.: Thermodynamics of the carbon dioxide system in the oceans, Geochim. Cosmochim. Ac., 59, 661-677, https://doi.org/10.1016/0016-7037(94)00354-O, 1995.

Millet, B., Pinazo, C., Daniela, B., Remi, P., Pierre, G., and Ivane, P.: Unexpected spatial impact of treatment plant discharges induced by episodic hydrodynamic events: Modelling Lagrangian transport of fine particles by Northern Current intru- 
sions in the bays of Marseille (France), PLoS One, 13, e0195257, https://doi.org/10.1371/journal.pone.0195257, 2018.

Millot, C.: The Gulf of Lions hydrodynamics, Cont. Shelf Res., 10, 885-894, https://doi.org/10.1016/0278-4343(90)90065-T, 1990.

Monterey, G. and Levitus, S.: Seasonal variability of mixed layer depth for the World Ocean, NOAA Atlas NESDIS 14, U.S. Dept. of Commerce, National Oceanic and Atmospheric Administration, National Environmental Satellite, Data, and Information Service, Washington, D.C., 1997.

Moran, M. A.: The global ocean microbiome, Sci. Am. Assoc. Adv. Sci., 350, https://doi.org/10.1126/science.aac8455, 2015.

Morris, A. W. and Riley, J. P.: The bromide/chlorinity and sulphate/chlorinity ratio in sea water, Deep Sea Res. Oceanogr. Abstr., 13, 699-705, https://doi.org/10.1016/0011-7471(66)906012, 1966.

Mucci, A.: The solubility of calcite and aragonite in seawater at various salinities, temperatures, and one atmosphere total pressure, Am. J. Sci., 283, 780-799, https://doi.org/10.2475/ajs.283.7.780, 1983.

Orr, J. C., Fabry, V. J., Aumont, O., Bopp, L., Doney, S. C., Feely, R. A., Gnanadesikan, A., Gruber, N., Ishida, A., Joos, F., Key, R. M., Lindsay, K., Maier-Reimer, E., Matear, R., Monfray, P., Mouchet, A., Najjar, R. G., Plattner, G.-K., Rodgers, K. B., Sabine, C. L., Sarmiento, J. L., Schlitzer, R., Slater, R. D., Totterdell, I. J., Weirig, M.-F., Yamanaka, Y., and Yool, A.: Anthropogenic ocean acidification over the twenty-first century and its impact on calcifying organisms, Nature, 437, 681-6, https://doi.org/10.1038/nature04095, 2005.

Pairaud, I., Gatti, J., Bensoussan, N., Verney, R., and Garreau, P.: Hydrology and circulation in a coastal area off Marseille: Validation of a nested 3D model with observations, J. Marine Syst., 88, 20-33, https://doi.org/10.1016/j.jmarsys.2011.02.010, 2011.

Para, J., Coble, P. G., Charrière, B., Tedetti, M., Fontana, C., and Sempéré, R.: Fluorescence and absorption properties of chromophoric dissolved organic matter (CDOM) in coastal surface waters of the northwestern Mediterranean Sea, influence of the Rhône River, Biogeosciences, 7, 4083-4103, https://doi.org/10.5194/bg-7-4083-2010, 2010.

Petrenko, A.: Variability of circulation features in the Gulf of Lion, NW Mediterranean Sea. Importance of inertial currents, Oceanol. Acta, 26, 323-338, https://doi.org/10.1016/S03991784(03)00038-0, 2003.

Pont, D., Simonnet, J.-P., and Walter, A. V.: Medium-term changes in suspended sediment delivery to the Ocean: Consequences of catchment heterogeneity and river management (Rhône River, France), Estuar. Coast. Shelf S., 54, 1-18, https://doi.org/10.1006/ecss.2001.0829, 2002.

Raven, J. A. and Falkowski, P. G.: Oceanic sinks for atmospheric $\mathrm{CO}_{2}$, Plant Cell Environ., 22, 741-755, https://doi.org/10.1046/j.1365-3040.1999.00419.x, 1999.

Riley, J. P.: The occurrence of anomalously high fluoride concentrations in the North Atlantic, Deep Sea Research and Oceanographic Abstracts, 12, 219-220, https://doi.org/10.1016/00117471(65)90027-6, 1965.

Riley, J. P. and Tongudai, M.: The major cation/chlorinity ratios in sea water, Chem. Geol., 2, 263-269, https://doi.org/10.1016/0009-2541(67)90026-5, 1967.

Roobaert, A., Laruelle, G. G., Landschützer, P., Gruber, N., Chou, L., and Regnier, P.: The spatiotemporal dynamics of the sources and sinks of $\mathrm{CO}_{2}$ in the global coastal ocean, Global Biogeochem. Cy., 33, https://doi.org/10.1029/2019GB006239, 2019.

Ross, O. N., Fraysse, M., Pinazo, C., and Pairaud, I.: Impact of an intrusion by the Northern Current on the biogeochemistry in the eastern Gulf of Lion, NW Mediterranean, Estuar. Coast. Shelf S., 170, 1-9, https://doi.org/10.1016/j.ecss.2015.12.022, 2016.

Rykiel, E. J.: Testing ecological models: The meaning of validation, Ecol. Model., 90, 229-244, https://doi.org/10.1016/03043800(95)00152-2, 1996.

Sarthou, G., Timmermans, K. R., Blain, S., and Tréguer, P.: Growth physiology and fate of diatoms in the ocean: a review, J. Sea Res., 53, 25-42, https://doi.org/10.1016/j.seares.2004.01.007, 2005.

Schneider, A., Wallace, D. W. R., and Körtzinger, A.: Alkalinity of the Mediterranean Sea, Geophys. Res. Lett., 34, https://doi.org/10.1029/2006GL028842, 2007.

Sempéré, R., Charrière, B., van Wambeke, F., and Cauwet, G.: Carbon inputs of the Rhône River to the Mediterranean Sea: Biogeochemical implications, Global Biogeochem. Cy., 14, 669-681, https://doi.org/10.1029/1999GB900069, 2000.

Small, C. and Nicholls, R. J.: A global analysis of human settlement in coastal zones, J. Coastal Res., 19, 584-599, available at: http:// www.jstor.org/stable/4299200 (last access: August 2019), 2003.

Smith, C. L. and Tett, P.: A depth-resolving numerical model of physically forced microbiology at the European shelf edge, J. Marine Syst., 26, 1-36, https://doi.org/10.1016/S09247963(00)00010-5, 2000.

Soetaert, K., Hofmann, A. F., Middelburg, J. J., Meysman, F. J. R., and Greenwood, J.: The effect of biogeochemical processes on $\mathrm{pH}$, Mar. Chem., 105, 30-51, https://doi.org/10.1016/j.marchem.2006.12.012, 2007.

Tett, P.: A three-layer vertical and microbiological processes model for shelf seas, Report No. 14. Proudman Oceanographic Laboratory, Birkenhead, UK, 85 pp., 1990.

Thingstad, T. F.: Utilization of N, P, and organic $\mathrm{C}$ by heterotrophic bacteria. I. Outline of a chemostat theory with a consistent concept of "maintenance" metabolism, Mar. Ecol. Prog. Ser., 35, 99109, https://doi.org/10.3354/meps035099, 1987.

Uppström, L. R.: The boron/chlorinity ratio of deep-sea water from the Pacific Ocean, Deep Sea Res. Oceanogr. Abstr., 21, 161-162, https://doi.org/10.1016/0011-7471(74)90074-6, 1974.

Upstill-Goddard, R. C.: Air-sea gas exchange in the coastal zone, Estuar. Coast. Shelf S., 70, 388-404, https://doi.org/10.1016/j.ecss.2006.05.043, 2006.

Wanninkhof, R. H.: Relationship between wind speed and gas exchange, J. Geophys. Res., 97, 7373-7382, 1992.

Weiss, R. F.: Carbon dioxide in water and seawater: the solubility of a non-ideal gas, Mar. Chem., 2, 203-215, https://doi.org/10.1016/0304-4203(74)90015-2, 1974.

Willmott, C. J.: Some comments on the evaluation of model performance, B. Am. Meteorol. Soc., 63, 1309-1313, https://doi.org/10.1175/15200477(1982)063<1309:SCOTEO>2.0.CO;2, 1982.

Wimart-Rousseau, C., Lajaunie-Salla, K., Marrec, P., Wagener, T., Raimbault, P., Lagadec, V., Lafont, M., Garcia, N., Diaz, F., Pinazo, C., Yohia, C., Garcia, F., Xueref-Remy, I., Blanc, P. E., Armengaud, A., and Lefèvre, D.: Temporal variability of the carbonate system and air-sea $\mathrm{CO}_{2}$ exchanges in a Mediter- 
ranean human-impacted coastal site, Estuar. Coast. Shelf S., 236, https://doi.org/10.1016/j.ecss.2020.106641, 2020.

Xueref-Remy, I., Milne, M., Zoghbi, N., Yohia, C., Armengaud, A., Blanc, P.-E., Delmotte, M., Piazzola, J., Nathan, B., Ramonet, M., and Lac, C.: Assessing atmospheric $\mathrm{CO}_{2}$ variability in the Aix-Marseille metropolis area (France) and its coastal Mediterranean Sea at different time scales within the AMC project, Prague, Aus, available at: https://conference.icos-ri.eu/wp-ontent/uploads/2018/ 09/ICOS2018SC_Book_of_Abstracts.pdf (last access: February 2020), 2018a.

Xueref-Remy, I., Dieudonné, E., Vuillemin, C., Lopez, M., Lac, C., Schmidt, M., Delmotte, M., Chevallier, F., Ravetta, F., Perrussel, O., Ciais, P., Bréon, F.-M., Broquet, G., Ramonet, M., Spain, T. G., and Ampe, C.: Diurnal, synoptic and seasonal variability of atmospheric $\mathrm{CO}_{2}$ in the Paris megacity area, Atmos. Chem. Phys., 18, 3335-3362, https://doi.org/10.5194/acp18-3335-2018, 2018.
Yohia, C.: Genèse du mistral par interaction barocline et advection $\mathrm{du}$ tourbillon potentiel, Climatologie, 13, 24-37, https://doi.org/10.4267/climatologie.1182, 2017.

Zappa, C. J., Raymond, P. A., Terray, E. A., and McGillis, W. R.: Variation in surface turbulence and the gas transfer velocity over a tidal cycle in a macro-tidal estuary, Estuaries, 26, 1401-1415, 2003 